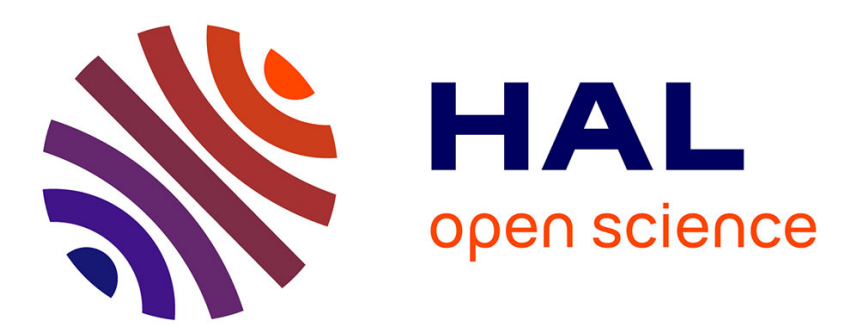

\title{
Secondary phloem in Early Carboniferous seed plants: anatomical diversity and evolutionary implications
}

\author{
Anne-Laure Decombeix, Jean Galtier, Brigitte Meyer-Berthaud
}

\section{To cite this version:}

Anne-Laure Decombeix, Jean Galtier, Brigitte Meyer-Berthaud. Secondary phloem in Early Carboniferous seed plants: anatomical diversity and evolutionary implications. International Journal of Plant Sciences, 2014, 175 (8), pp.891-910. 10.1086/677650 . hal-01076111

\section{HAL Id: hal-01076111 \\ https://hal-sde.archives-ouvertes.fr/hal-01076111}

Submitted on 26 May 2021

HAL is a multi-disciplinary open access archive for the deposit and dissemination of scientific research documents, whether they are published or not. The documents may come from teaching and research institutions in France or abroad, or from public or private research centers.
L'archive ouverte pluridisciplinaire HAL, est destinée au dépôt et à la diffusion de documents scientifiques de niveau recherche, publiés ou non, émanant des établissements d'enseignement et de recherche français ou étrangers, des laboratoires publics ou privés. 
Secondary Phloem in Early Carboniferous Seed Plants: Anatomical Diversity and Evolutionary Implications

Author(s): Anne-Laure Decombeix, Jean Galtier, and Brigitte Meyer-Berthaud

Source: International Journal of Plant Sciences, Vol. 175, No. 8 (October 2014), pp. 891-910

Published by: The University of Chicago Press

Stable URL: http://www.jstor.org/stable/10.1086/677650

Accessed: 08/10/2014 04:18

Your use of the JSTOR archive indicates your acceptance of the Terms \& Conditions of Use, available at http://www.jstor.org/page/info/about/policies/terms.jsp

JSTOR is a not-for-profit service that helps scholars, researchers, and students discover, use, and build upon a wide range of content in a trusted digital archive. We use information technology and tools to increase productivity and facilitate new forms of scholarship. For more information about JSTOR, please contact support@jstor.org. 
Int. J. Plant Sci. 175(8):891-910. 2014.

(c) 2014 by The University of Chicago. All rights reserved.

1058-5893/2014/17508-0002\$15.00 DOI: $10.1086 / 677650$

\title{
SECONDARY PHLOEM IN EARLY CARBONIFEROUS SEED PLANTS: ANATOMICAL DIVERSITY AND EVOLUTIONARY IMPLICATIONS
}

\author{
Anne-Laure Decombeix, ${ }^{1, *}$ Jean Galtier, ${ }^{*}$ and Brigitte Meyer-Berthaud* \\ *Centre National de la Recherche Scientifique and Université Montpellier 2, Unité Mixte de Recherche Botanique \\ et Bioinformatique de l'Architecture des Plantes (AMAP), Montpellier F-34000, France
}

Editor: Michael T. Dunn

\begin{abstract}
Premise of research. Secondary phloem produced by a bifacial vascular cambium is the distinctive feature of lignophytes, the group that comprises the seed plants and the progymnosperms. Because secondary phloem is rarely well preserved in the fossil record, our knowledge of the evolution of this tissue remains incomplete.

Methodology. We illustrate the secondary phloem anatomy of nine seed plants of Mississippian (Early Carboniferous) age that represent to date the oldest representatives of the group in which this tissue is well preserved. In addition, we review the information available on the secondary phloem anatomy of Devonian progymnosperms and Late Carboniferous-Permian seed plants.

Pivotal results. Secondary phloem anatomy was already diversified in the Mississippian seed plants, in terms of cell composition and spatial organization of the different cell types. We propose four models of secondary phloem anatomy and organization in lignophytes of Devonian-Carboniferous age.

Conclusions. The diversity of secondary phloem anatomy in Mississippian seed plants parallels what is observed for other parts of their vascular system; it is most likely linked to the Mississippian diversification of seed plant growth architectures and habitats. The accumulated fossil evidence also demonstrates that several characters that have been considered as advanced on the basis of the study of extant gymnosperms (e.g., the presence of fibers in the functional phloem and the arrangement in alternate tangential layers of a same cell type) were actually already present in some early representatives of the lignophytes.
\end{abstract}

Keywords: Carboniferous, Mississippian, seed plants, progymnosperms, secondary phloem, evolution.

\section{Introduction}

Seed plants, the monophyletic group comprising gymnosperms and angiosperms, have been a major component of terrestrial ecosystems since the Carboniferous. The oldest evidence of plants with a reproduction by seed/ovule dates from the Late Devonian, about $370 \mathrm{Myr}$ ago, and at that time the fossil record indicates a significant diversification of their reproductive structures (Prestianni et al. 2013). In contrast, the scarce information available on the corresponding vegetative systems suggests the existence of a single dominant type of vegetative body plan for these early seed plants (Prestianni and Decombeix 2013). They possessed small protostelic stems with little development of the secondary vascular tissues and are reconstructed as bushy plants growing in disturbed habitats (e.g., Galtier 1988; Serbet and Rothwell 1992; Dunn 2006 and references therein).

The Early Carboniferous (Mississippian) fossil record, on the other hand, shows a significant diversification of the seed plant vegetative body. Anatomical evidence and biomechanical modeling indicate that Mississippian seed plants ranged in

1 Author for correspondence; e-mail: anne-laure.decombeix@cirad.fr.

Manuscript received March 2014; revised manuscript received May 2014; electronically published September 17, 2014. growth architecture from leaning or semi-self-supporting taxa a few centimeters in diameter (e.g., Calamopitys; Rowe et al. 1993; Masselter et al. 2009) to large trees reaching at least 2 $\mathrm{m}$ in diameter (e.g., Pitus; Long 1979; Galtier 2002). This diversification of growth architecture is paralleled by a diversification of the anatomy of the primary and secondary vascular systems. This anatomical diversification concerns such characters as stele types, size and distribution of cauline primary xylem strands, mode of leaf trace emission, leaf trace anatomy, ray size, and secondary xylem tracheid radial pitting (Galtier 1988; Galtier and Meyer-Berthaud 2006; Decombeix et al. 2011a). An aspect that is less well known is the anatomy of the secondary phloem, the tissue responsible for the transport of carbohydrates, hormones, and other metabolites through these plants. Secondary phloem is rarely well preserved in the fossil record, and its anatomy in the first seed plants of the Late Devonian remains unknown (e.g., Serbet and Rothwell 1992). It is also unknown or not developed in Mississippian seed plants of small stature, such as Tetrastichia (Gordon 1938; Dunn and Rothwell 2012) and Tristichia (Long 1961; Galtier and Meyer-Berthaud 1996). However, there are a significant number of Mississippian putative seed plant axes where secondary phloem can be observed in detail, and information available in the literature strongly suggests that this 
tissue also underwent an anatomical diversification during that period (Galtier and Meyer-Berthaud 2006).

In this context, the first objective of this article is to review and illustrate the secondary phloem composition and organization in several Early Carboniferous taxa with seed plant affinities. We then synthesize the data available for progymnosperms and Late Carboniferous seed plants. We propose four models of secondary phloem composition and organization in Devonian-Carboniferous plants. The results are discussed in the context of the diversification of seed plant vegetative anatomy during the Mississippian and its possible link to the diversification of their growth architecture and habitats. Finally, we compare the information provided by the Devonian and Carboniferous fossils to some of the trends in secondary phloem evolution that have been proposed on the basis of the study of extant seed plants.

\section{Material and Methods}

\section{Material}

The nine anatomically preserved Mississippian taxa used in this study have all been previously described, but with various attention paid to their secondary phloem. This tissue was described in detail for Calamopitys embergeri (Galtier and Hébant 1973), Stanwoodia kirktonense (Galtier and Scott 1991), and an unnamed Australian tree (Decombeix 2013). For the other taxa, the presence of the secondary phloem was mentioned and its anatomy partly described and/or illustrated.

The taxa come from five different localities of Early and Middle Mississippian age: (1) Montagne Noire, France (Lydienne Formation, Middle Tournaisian, Lower Mississippian)-Calamopitys embergeri (Galtier and Hébant 1973), Calamopitys schweitzeri (Galtier et al. 1993b), Faironia difasciculata (Decombeix et al. 2006), and Lyginopitys puechcapelensis (Galtier 1970); (2) Weaklaw, Scotland (Gullane Formation, Upper Visean, Middle Mississippian)_Bilignea solida and Eristophyton fasciculare (Galtier et al. 1993a); (3) East Kirkton, Scotland (East Kirkton Limestone, Upper Visean, Middle Mississippian)-Eristophyton fasciculare (Galtier and Scott 1994) and Stanwoodia kirktonensis (Galtier and Scott 1991); (4) Dotswood, Queensland, Australia (Percy Creek Volcanics, Middle Tournaisian, Lower Mississippian)—unnamed taxon of Decombeix (2013); and (5) Hassi-t-in-Etenaï, Ahnet region, Algeria (Tibaradine Sandstones, Upper Tournaisian, Lower Mississippian)_ “new taxon 3" of Galtier and MeyerBerthaud (2006).

All studied slides belong to the Collections de Paléobotanique, Universite Montpellier 2, except the ones of the Dotswood trees with bark, which are part of the collections of the Smithsonian Institution, Washington, DC (temporary loan to Université Montpellier 2). Specimen and slide numbers are provided in the figure legends.

\section{Photography}

All specimens have been prepared for previous studies as classical thin sections (Hass and Rowe 1999) or peel sections (Galtier and Phillips 1999). Observation and photography for this article were conducted using a Sony XCD-U100CR digital camera attached to an Olympus BX51 compound microscope.
Images were captured using Archimed software (Microvision Instruments, Evry, France), and plates were composed with Adobe Photoshop CS5 (ver. 12.0; Adobe Systems, San Jose, CA). Some images are composites of several photos in different focal planes created with the multifocus option of Archimed; these are indicated in the legends by "fs" (focused stack). All photographs are oriented with the inside of the stem toward the bottom for transverse section and toward the left for longitudinal sections.

\section{Descriptions of Secondary Phloem in Mississippian Seed Plants}

For each taxon, we provide the following information: (1) cell types present in the secondary phloem, (2) arrangement of the different cell types, and (3) anatomical changes between inner and outer phloem. In addition, we provide detailed anatomical photographs of each taxon (figs. 1-6) and diagrams (fig. 7). Details of cell size are not provided, as the present study focuses on the qualitative characters of the phloem; they are either documented in the original descriptions or can be observed on the present illustrations. In cases where sieve areas are not preserved, putative sieve cells in the young phloem have been distinguished from axial parenchyma cells by their significantly more elongated shape in longitudinal section and, in some cases, by their diameter.

\section{Calamopitys embergeri (Galtier and Hébant 1973, Fig. 1A-1E)}

The secondary phloem has been observed in ca. 1-cm-wide stems. It contains bi- to triseriate rays, axial parenchyma, and sieve cells (fig. 1A-1E). At least some of the axial parenchyma cells are higher than wide in longitudinal section and appear to have connections with adjacent sieve cells (fig. $1 E$ ). It is possible that they are equivalent to the albuminous cells of extant gymnosperms (Esau 1969; Beck 2005).

The phloem tissue is arranged in repeated tangential layers of axial parenchyma and sieve cells (fig. $1 A, 1 B$ ). Sieve cells have a diameter comparable to that of the outermost secondary xylem tracheids, while parenchyma cells are significantly smaller. Only a small amount of secondary phloem is produced, and there are no observable changes in the axial system between the inner and outer part of the tissue. Rays, on the other hand, tend to enlarge toward the outer part, both by an increase in the tangential diameter of ray cells and, occasionally, by their division (fig. $1 B$ ).

\section{Calamopitys schweitzeri (Galtier et al. 1993a; Fig. 1F-1H)}

Stems of C. schweitzeri (up to $5 \mathrm{~cm}$ in diameter) have a secondary phloem comparable to that of C. embergeri but contain a larger number of tangential layers. It consists of rays that are two to eight cells wide, axial parenchyma, and sieve cells (fig. $1 G, 1 H$ ). The rays enlarge significantly from the cambium to the outer part of the phloem, both by increase in cell tangential diameter and by cell division (fig. $1 F, 1 G$ ). 


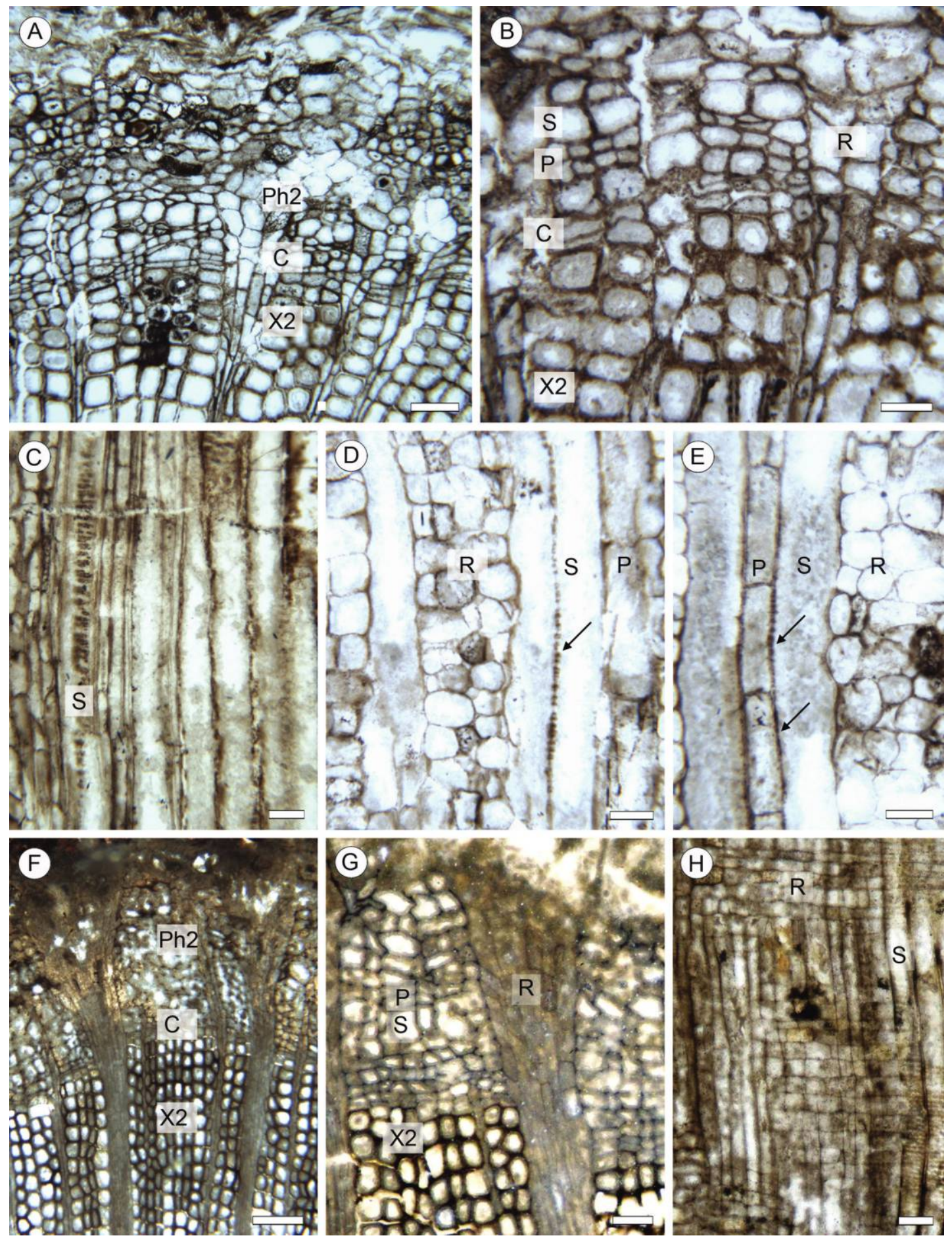

Fig. 1 Secondary phloem anatomy in Calamopitys from the Early Mississippian of Montagne Noire, France. A-E, Calamopitys embergeri. F$H$, Calamopitys schweitzeri. A, General view of the stem periphery in C. embergeri showing the secondary xylem, secondary phloem, and cortex in transverse section. Note the enlargement of rays in the secondary phloem. MN286-Bi14. B, Detail of the cambium zone, secondary xylem, and secondary phloem in transverse section. MN286-Bi14. C, Longitudinal section of secondary phloem showing sieve areas on the radial wall of a sieve cell. MN286-Cl58. D, Tangential section of secondary phloem with high multiseriate phloem rays, sieve cells with sieve areas (arrow), and axial parenchyma. MN286-Cl23. E, Tangential section of secondary phloem showing possible connections (arrows) between a sieve cell and adjacent axial parenchyma cells. MN286-Cl20. F, General view of a C. schweitzeri stem showing the secondary xylem and secondary phloem in transverse section. Note the enlargement of rays in the secondary phloem. MN418-Ci01. G, Detail of $F$ showing the cambium region, secondary phloem with parenchyma and sieve cells, and an enlarged phloem ray. MN418-Ci01. H, Radial section in the secondary phloem showing rays and sieve cells. MN418-Ci01. $\mathrm{C}=$ cambium zone, $\mathrm{P}=$ axial parenchyma, $\mathrm{Ph} 2=$ secondary phloem, $\mathrm{R}=$ ray, $\mathrm{S}=$ sieve cell, $\mathrm{X} 2=$ secondary xylem. Scale bars: $A, G, H=100 \mu \mathrm{m} ; B-E=50 \mu \mathrm{m} ; F=250 \mu \mathrm{m}$. 
Faironia difasciculata (Decombeix
et al. 2006; Fig. 2A-2C)

This taxon is known from only one specimen, which is 3.4 $\mathrm{cm}$ wide and possesses a small amount of preserved secondary phloem on one side of the stem (fig. $2 A-2 C$ ). The tissue is composed of rays and an axial system containing fibers and two types of thin-walled cells; the longitudinally elongated ones are interpreted as sieve cells and the others as axial parenchyma. In transverse sections, fibers seem to be arranged in several-cell-wide tangential layers. Some ray cells have a dark content or are sclerified (fig. 2B). Due to the small amount of tissue and only partial preservation, it is impossible to clearly observe the existence of any change between the inner and outer part of the tissue.

\section{Lyginopitys puechcapelensis (Galtier 1970; Fig. 2D-2J)}

Secondary phloem in this taxon was observed in specimens up to $1.5 \mathrm{~cm}$ wide in diameter. The secondary phloem is composed of multiseriate rays, fibers, and thin-walled cells corresponding to sieve cells and axial parenchyma (fig. $2 \mathrm{D}-2 \mathrm{H}$ ). Rays are very conspicuous, are three to eight cells wide, and often appear very dark (fig. $2 D-2 F$ ). At least some of the cells in the dark parts of the rays are sclerified (fig. $2 I, 2 J$ ).

The fibers tend to occur in tangential layers of one to two cells that are more or less continuous and alternate with layers of thin-walled cells that are one to three cells in thickness (fig. $2 D-2 F)$. This arrangement is seen from the cambium to the outer part of the phloem. Tangential sections in the innermost part show elongated thin-walled cells corresponding to sieve cells between the layers of fibers (fig. $2 G, 2 H$ ). The arrangement appears to be sieve cell, fiber, sieve cell, and parenchyma (S-F-S-P); several cells of a same type can be present in each layer (fig. 2H). However, no clear sieve area has been observed, so it is unknown whether this arrangement is constant. Farther out in the phloem, layers of fibers appear closer to each other tangentially than they are in the inner phloem, and only axial parenchyma is recognizable within the layers of thin-walled cells (fig. $2 D-2 F$ ). This probably results from the occlusion of the sieve cells. Rays are much enlarged in the outer part of the phloem, by increase in the tangential diameter of their cells and by some cell division.

\section{Eristophyton fasciculare (Galtier et al. 1993b; Galtier and Scott 1994; Fig. 3)}

Specimen EK2007 from East Kirkton (Galtier and Scott $1994)$ is $2.5 \mathrm{~cm}$ in diameter. It is the known specimen of $E$. fasciculare with the best-preserved secondary phloem, and it shows the changes between the inner and outer part of the tissue. Two other specimens, one from East Kirkton and one slightly larger from Weaklaw $(3.3 \mathrm{~cm}$ in diameter; Galtier et al. 1993a), show a comparable organization. The phloem is composed of rays, fibers, sieve cells, and axial parenchyma cells, some with dark content (fig. 3). The fibers occur in tangential layers of one to two cells that are more or less continuous tangentially. They alternate with layers of thin-walled cells that are one to three cells thick (fig. $3 A-3 G$ ). Although the cambium region is missing or badly preserved, fibers can be observed relatively close to the probable location of the cambium (fig. 3B, 3C). Rays are mostly uniseriate in the inner part of the phloem but enlarge significantly in the outer part, both by a tangential enlargement of their cells and by cell division that produces wide biseriate rays in the outermost part (fig. $3 D, 3 E$ ). The proportion of thin-walled cells does not increase significantly toward the outside, and the regular arrangement of fibers and thin-walled cell layers remains constant. The main difference is the presence of sieve cells in the inner part (fig. $3 H$ ), while in the older phloem only axial parenchyma can be observed between the layers of fibers (fig. 3I).

\section{Stanwoodia kirktonensis (Galtier and Scott 1991; Fig. 4)}

Two specimens ( 3 and $2.4 \mathrm{~cm}$ wide) with preserved phloem are known from the same locality (fig. $4 A, 4 F$ ). The bark is of the rhytidome type, with sequential periderms separating layers of old phloem. The secondary phloem is up to $1.5 \mathrm{~mm}$ thick. It contains rays and an axial system composed of fibers, thin-walled cells corresponding to axial parenchyma, and putative sieve cells (fig. 4A-4G) as well as thin-walled cells with a dark content that tend to be arranged in vertical rows of a few cells (fig. $4 E$, arrow). Tangential layers of fibers alternate with layers of thin-walled cells. These layers of fibers tend to be discontinuous and are usually only one cell thick. In the outer part of the secondary phloem tissues, thin-walled cells with no content occupy a larger surface area, indicating a proliferation of the axial parenchyma as the tissue ages. Rays are not easy to distinguish but do not appear to enlarge significantly in the older phloem.

\section{Bilignea solida (Galtier et al. 1993b; Fig. 5)}

The specimen with preserved secondary phloem has a maximum diameter of $2.5 \mathrm{~cm}$. The secondary phloem tissue is composed of thick-walled cells, thin-walled cells, and conspicuous enlarged cells with dark content (fig. 5). In longitudinal section, most cells appear to be elongated, and the thickand thin-walled cells are thus interpreted respectively as fibers and sieve cells (fig. 5F, 5H). Axial parenchyma cells are also present and are higher than wide in longitudinal section. The cells with dark content are larger than the others in transverse section and are higher than wide in longitudinal section (e.g., fig. $5 B, 5 C, 5 G, 5 H)$; they are interpreted as secretory/resinous structures. While the tissue is distorted in most places, the cell arrangement is in tangential layers with multicellular layers of thin-walled cells alternating with unicellular layers of fibers (fig. 5B, 5C). This arrangement can be seen even very close to the cambium, indicating that the fibers were part of the inner, presumably functional phloem. The secretory/resinous structures are also arranged in tangential layers. They occur within the layers of thin-walled cells (fig. $5 B-5 D$ ) but are not present in each of these layers (fig. 5B).

Toward the outer part of the tissue, the secretory/resinous cells are much enlarged, while the sieve cells are more or less crushed and only the fibers keep their original shape and size (fig. 5A, 5D). Rays do not appear to enlarge significantly. 

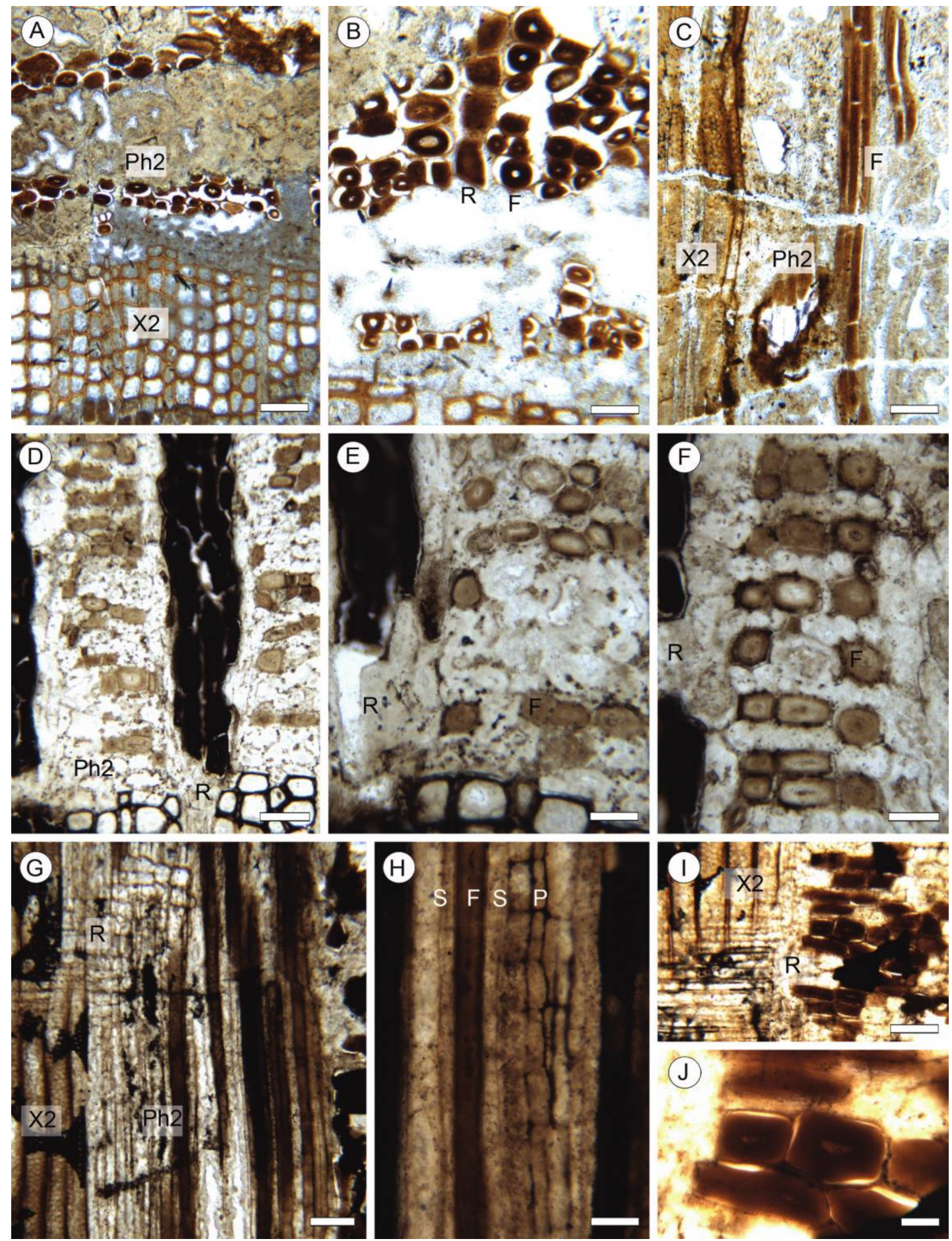

Fig. 2 Secondary phloem anatomy in Faironia difasciculata $(A-C)$ and Lyginopitys puechcapelensis $(D-J)$ from the Early Mississippian of Montagne Noire. A, Secondary xylem and secondary phloem of Faironia in transverse section. MN266-Ei. B, Detail of the cambium zone of Faironia and secondary phloem in transverse section. MN266-Ei. C, Radial section of Faironia showing secondary xylem, cambium zone (not preserved), and phloem with fibers. MN266-C2. D, Secondary xylem and secondary phloem of Lyginopitys in transverse section. Note the dark ray cells. MN404-BS1. E, Detail of the cambium zone and inner secondary phloem with fibers in Lyginopitys. MN404-BS1. F, Detail of the older secondary phloem in Lyginopitys showing tangential layers of fibers alternating with layers of thin-walled cells. MN404-BS1. G, Radial section of Lyginopitys showing secondary xylem, cambium zone, rays, and phloem with fibers. MN973-Ai01. H, Radial section of Lyginopitys inner secondary phloem showing the alternation of fibers and thin-walled cells. The latter are either very long and interpreted as sieve cells or short and interpreted as axial parenchyma. MN973-Ai01. I, Radial section of Lyginopitys showing a ray across the outer secondary xylem, cambium, and inner secondary phloem. MN973-Ai02. J, Detail of ray in $I$ showing the sclerified wall of ray cells in the secondary phloem. MN973-Ai02. F $=$ fiber, $\mathrm{P}=$ axial parenchyma, $\mathrm{Ph} 2=$ secondary phloem, $\mathrm{R}=$ ray, $\mathrm{S}=$ sieve cell, $\mathrm{X} 2=$ secondary xylem. Scale bars: $A, C, D, G, I=100 \mu \mathrm{m} ; B, E, F, H=50 \mu \mathrm{m} ; J=25 \mu \mathrm{m}$. 

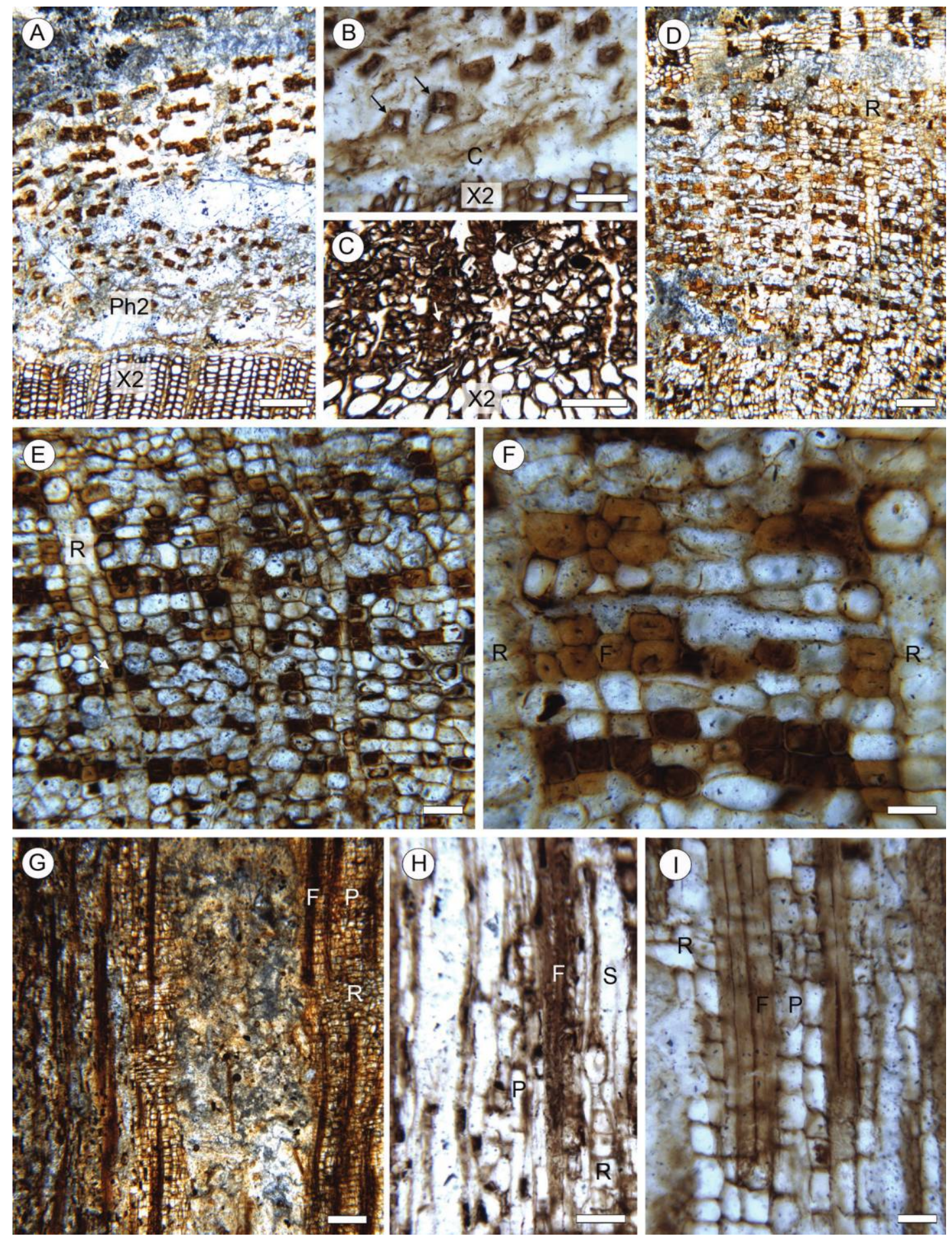

Fig. 3 Secondary phloem anatomy in Eristophyton fasciculare from the Middle Mississippian of East Kirkton $(A, B, D-I)$ and Weaklaw $(C)$, Scotland. A, Secondary xylem and inner part of the secondary phloem in transverse section. EK2007-Ct1. $B$, Higher magnification of the specimen from East Kirkton illustrated in $A$ showing the outermost secondary xylem tracheids, the cambium zone (not preserved), and the innermost part of the phloem with a few preserved fibers at arrows. EK2007-Ct1 (fs). C, Transverse section of the youngest secondary phloem, which is distorted but confirms the presence of thick-walled cells very close to the cambium (arrow). WR03-J2t01. D, Well-preserved old secondary phloem in the outer part of the specimen from East Kirkton. Note the enlargement of rays. EK2007-Ct1. E, Detail of the old phloem showing the increase in ray cell number (arrow). EK2007-Ct1. F, Detail of the old phloem showing tangential layers of axial parenchyma cells alternating with layers of fibers. EK2007-Ct1. G, General view of the secondary phloem in radial section showing the alternation between layers of fibers and thin-walled cells. EK2007-C1bLR01. H, Inner part of the secondary phloem in tangential oblique section, showing a ray, putative sieve cells, axial parenchyma, and fibers. EK2007-C1aLR02. I, Radial section in the old phloem with alternation of fibers and axial parenchyma. EK2007-C1aLR02 (fs). C = cambium zone, $\mathrm{F}=$ fiber, $\mathrm{P}=$ axial parenchyma, $\mathrm{Ph} 2=$ secondary phloem, $\mathrm{R}=$ ray, $\mathrm{S}=$ sieve cell, $\mathrm{X} 2=$ secondary xylem. Scale bars: $A, D, G=250$ $\mu \mathrm{m} ; B, C, E, H=100 \mu \mathrm{m} ; F, I=50 \mu \mathrm{m}$. 


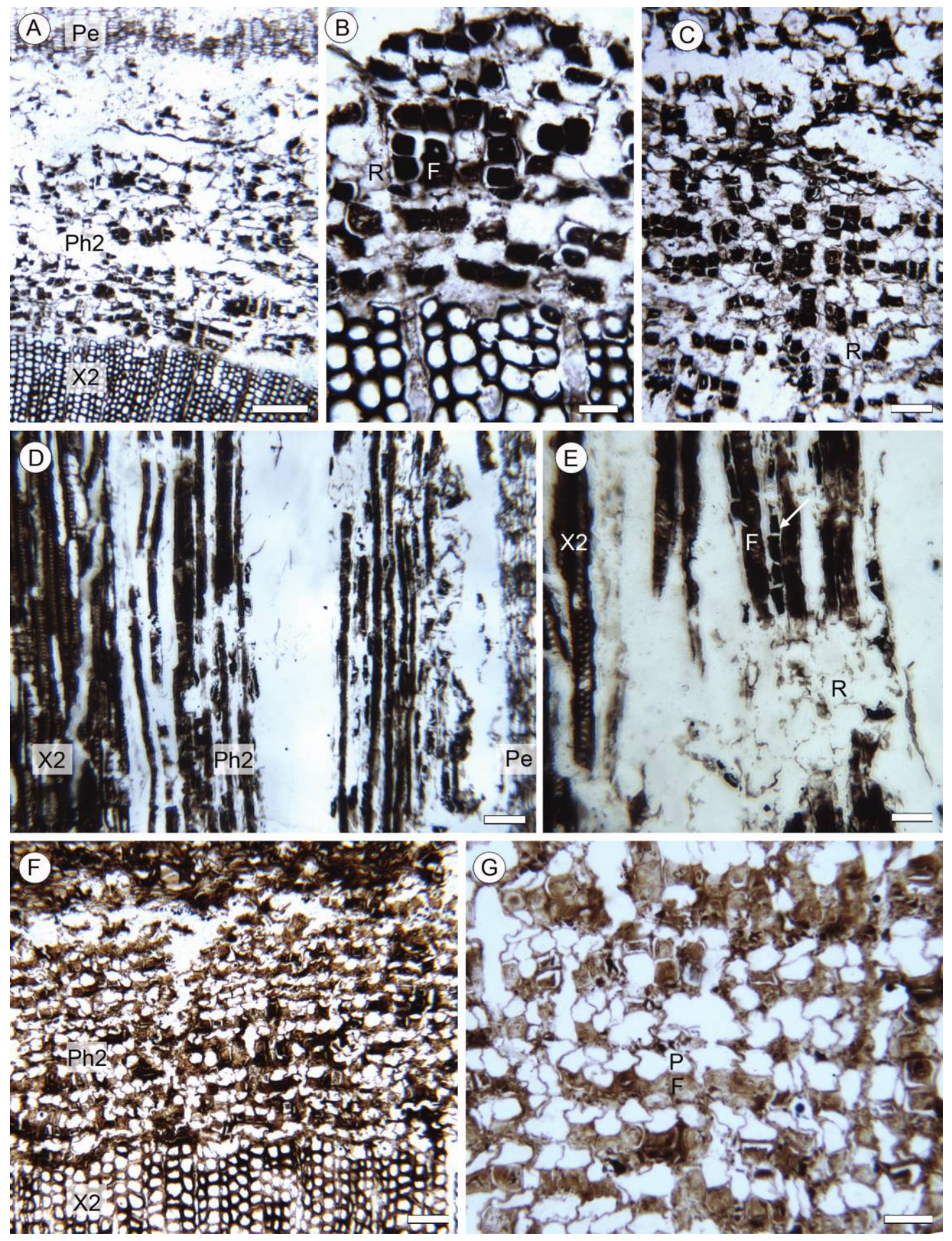

Fig. 4 Secondary phloem anatomy in Stanwoodia kirktonense from the Middle Mississippian of East Kirkton, Scotland. A-E, Holotype. F-G, Second specimen. A, Secondary xylem and inner part of the secondary phloem in transverse section. EKpb4860-Ai01. B, Detail of the outermost secondary xylem tracheids, cambium zone, and innermost part of the phloem with fibers and thin-walled cells with dark content. EKpb4860-Ai01. $C$, Old phloem showing the dilatation of the parenchyma and the distribution of fibers. EKpb4860-Ai01. D, General view of the secondary phloem in radial section, with secondary xylem on the left and periderm layer on the right. Only fibers are conspicuous. EKpb4860-CbLR04 (fs). E, Detail of the innermost secondary phloem in longitudinal section showing fibers, a ray, and remains of axial parenchyma with dark content (arrow). EKpb4860-CbLR04 (fs). F, General view of the secondary phloem of the second specimen in transverse section. EKpb4860-Cs01. G, Detail of the secondary phloem of the second specimen showing alternating layers of thin-walled cells and fibers. EKpb4860-Cs01. $\mathrm{C}=$ cambium zone, $\mathrm{F}=$ fiber, $\mathrm{P}=$ axial parenchyma, $\mathrm{Pe}=$ periderm, $\mathrm{Ph} 2=$ secondary phloem, $\mathrm{R}=$ ray, $\mathrm{S}=$ sieve cell, $\mathrm{X} 2=$ secondary xylem. Scale bars: $A=250$ $\mu \mathrm{m} ; B, E, G=50 \mu \mathrm{m} ; C, D, F=100 \mu \mathrm{m}$. 

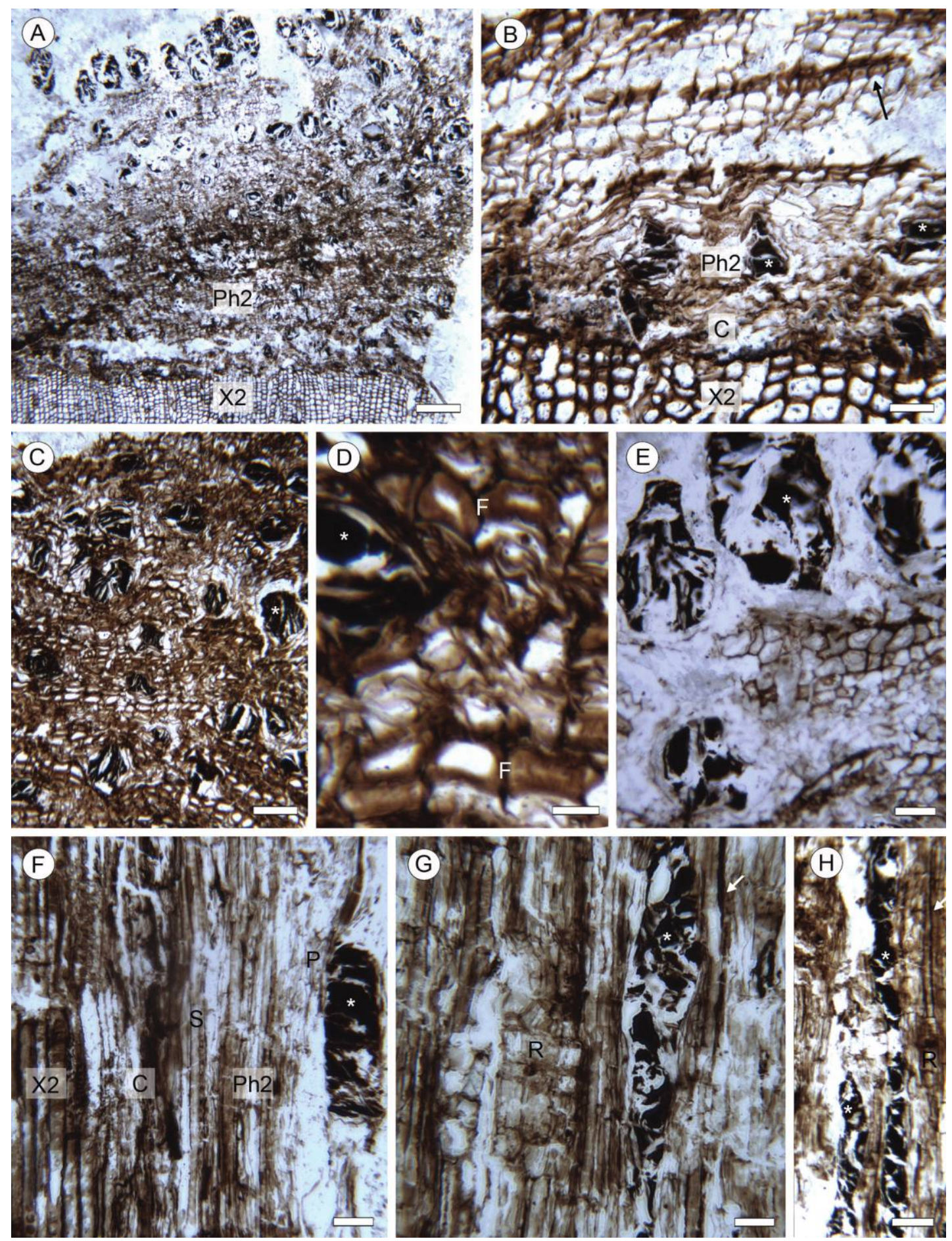

Fig. 5 Secondary phloem anatomy in Bilignea solida from the Middle Mississippian of Weaklaw, Scotland. A, General view of secondary xylem and secondary phloem in transverse section. WR03-Eb02. B, Detail of the outermost secondary xylem tracheids, cambium zone, and innermost part of the phloem with thin-walled cells, thick-walled cells (arrow), and large cells with dark content (asterisks). WR03-Cs03. C, Old phloem in transverse section showing the alternation of tangential layers of thick-walled cells and partly crushed thin-walled cells containing large secretory structures. WR03-Cs03. D, Detail of thick-walled cells in the zone illustrated in C. WR03-Cs03 E, Outermost part of the phloem in transverse section (corresponding to the top part of $A$ ), with greatly enlarged secretory structures. WR03-Eb02. F, Longitudinal section through the outermost secondary xylem, cambium zone, and inner phloem composed of sieve cells, parenchyma, and a secretory structure. WR03-tls16. G, Radial section of the secondary phloem showing a ray a few cells in height, thin-walled cells of the axial system, a secretory structure, and one elongated cell with a thicker wall (arrow). WR03-tls16. H, Longitudinal section in old phloem showing a very high secretory structure and an elongated cell with a thicker wall (arrow). WR03-tls16. Asterisk = secretory cell, $\mathrm{C}=$ cambium zone, $\mathrm{F}=$ fiber, $\mathrm{P}=$ axial parenchyma, $\mathrm{Ph} 2=$ secondary phloem, $\mathrm{R}=$ ray, $\mathrm{S}=$ sieve cell, $\mathrm{X} 2=$ secondary xylem. Scale bars: $A=250 \mu \mathrm{m} ; B, E-G=50 \mu \mathrm{m} ; C, H=100 \mu \mathrm{m} ; D=25 \mu \mathrm{m}$. 


\section{Unnamed Australian Taxon (Decombeix} 2013; Fig. 6A-6C)

Large gymnosperm trunks (up to $30 \mathrm{~cm}$ in diameter) from the locality of Dotswood have a well-preserved bark. While the wood anatomy of these trunks is comparable to that of Pitus and Eristophyton, their secondary phloem anatomy is quite distinct. The bark is of the rhytidome type (fig. 6A) and is more than $1 \mathrm{~cm}$ thick. The secondary phloem is composed of uni- to biseriate rays, fibers, sieve cells, and axial parenchyma (fig. 6A-6C). The fibers form conspicuous layers up to 9 cells thick. They alternate with layers of thin-walled cells (fig. 6B). In the inner part of the secondary phloem, close to the cambium, there is evidence of longitudinally elongated thin-walled cells corresponding to sieve cells between the layers of fibers (fig. 6C). In the older phloem, axial parenchyma cells occupy these areas, probably as a combined result of the occlusion of the sieve cells and proliferation of the parenchyma (fig. 6A). The proliferation of the axial parenchyma gives a much more parenchymatous aspect to the tissue and pushes the layers of fibers farther apart (fig. 6A). Rays in these regions remain of a comparable size.

\section{Unnamed Algerian Taxon ("New Taxon 3" of Galtier and Meyer-Berthaud 2006; Fig. 6D-6I)}

This 3.5-cm-wide stem from the Tournaisian of Algeria shows a well-preserved secondary phloem. The zone corresponding to the location of the cambium is not well preserved; in cross section it is usually indicated by a dark band (fig. $6 \mathrm{D}$, $6 E, 6 G, 6 H)$. Four types of cells can be distinguished in the secondary phloem: ray cells, fibers, axial parenchyma, and putative sieve cells. In the innermost (youngest) part, the phloem is mostly composed of fibers, uni- to biseriate rays, and a few putative sieve cells and axial parenchyma cells (fig. 6E, 6H). In the older phloem, tangential layers of fibers five to nine cells in thickness are separated by multicellular layers of parenchyma with a few isolated fibers (fig. 6F). As a result, the outer part of the phloem has a more parenchymatous aspect than the inner part. This is interpreted as the result of an enlargement of axial parenchyma cells-and possibly their proliferation-as the tissue matures. Cellular divisions within some of the thin-walled cell layers indicate the probable level at which a new periderm layer would have been formed (fig. 6I).

\section{Secondary Phloem in Other Devonian- Carboniferous Lignophytes (Table 1)}

To see how the anatomical diversity of the secondary phloem in Mississippian seed plants compares to what is known in lignophytes before and after that time, we reviewed the literature on the Devonian progymnosperms and on seed plants of Pennsylvanian age. Table 1 and figure 7 present the references and some of the secondary phloem characters of the taxa mentioned in this article.

\section{Progymnosperms}

The progymnosperms (Beck 1960) are a paraphyletic extinct group of plants that shared the possession of a bifacial vascular cambium with the seed plants but had free-sporing reproduc- tion. Phylogenetic analyses recognize them as the group from which the seed plants have evolved, and together the progymnosperms and seed plants form the lignophyte clade (Rothwell and Serbet 1994; Kenrick and Crane 1997; Hilton and Bateman 2006). The progymnosperms contains three orders: the Aneurophytales (Middle and Late Devonian), the Archaeopteridales (Middle and Late Devonian), and the Protopityales (Mississippian; Beck and Wight 1988). Other taxa that are sometimes included within the progymnosperms are the Pennsylvanian taxa Cecropsis (Stubblefield and Rothwell 1989) and the Noeggerathiales (Carboniferous-Triassic). However, secondary phloem is unknown in these taxa, and they will not be discussed here.

The oldest progymnosperms belong to the Aneurophytales. This group comprises branched plants with small ultimate vegetative appendages (no true leaves) and homosporous reproduction. A biomechanical study of aneurophytalean axes (Tetraxylopteris; Speck and Rowe 2003) has shown that at least some of those taxa were not fully self-supporting. More recently, Stein et al. (2012) hypothesized, on the basis of taphonomic evidence, that their growth architecture consisted of a large, woody rhizome bearing small rootlets and erect branches. Secondary phloem anatomy is well known in three different genera of Aneurophytales: Tetraxylopteris, Triloboxylon, and Proteokalon (Beck 1957; Scheckler and Banks 1971a, 1971b; Stein and Beck 1983). In these three genera, the secondary phloem is a complex tissue composed of rays, fibers, sclereids, axial parenchyma, secretory/tannin cells, and sieve cells. This tissue is generally narrow, with only a few layers of cells. It consists of radially aligned rows of fibers with some interposed thin-walled cells corresponding to parenchyma and sieve cells. There is no evidence of any arrangement of similar cell types in successive tangential layers.

The second group of progymnosperms for which secondary phloem anatomy is documented is the Archaeopteridales, known from the Middle Devonian to the Devonian-Carboniferous boundary. This group includes the first lignophytes to have evolved the tree habit (Meyer-Berthaud et al. 1999), which makes the study of their vascular system particularly meaningful. Early studies of the bark tissues of archaeopteridalean stems (called Callixylon) by Arnold (1930a) and Lemoigne et al. (1983) concluded that the phloem of these plants was much simpler than that of the aneurophytalean progymnosperm and did not contain fibers or sclereids. However, more recent studies of archaeopteridalean roots and of a trunk from the Late Devonian of Morocco show that the secondary phloem of at least some archaeopteridaleans indeed contained fibers and sclereids (Decombeix and Meyer-Berthaud 2013; Meyer-Berthaud et al. 2013). In archaeopteridalean progymnosperms, the different cell types clearly tend to form tangentially oriented layers (Arnold 1930a; Lemoigne et al. 1983; Decombeix and Meyer-Berthaud 2013). Accommodation to the increase in circumference of the axes occurs by dilatation of axial parenchyma cells, while rays cells remain of a more or less constant size and number (Decombeix and MeyerBerthaud 2013).

In the third group of progymnosperms, the Early Carboniferous Protopityales, the anatomy of the secondary phloem remains uncertain and contradictory. The arborescent species of the order, Protopitys buchiana, was interpreted by Walton 

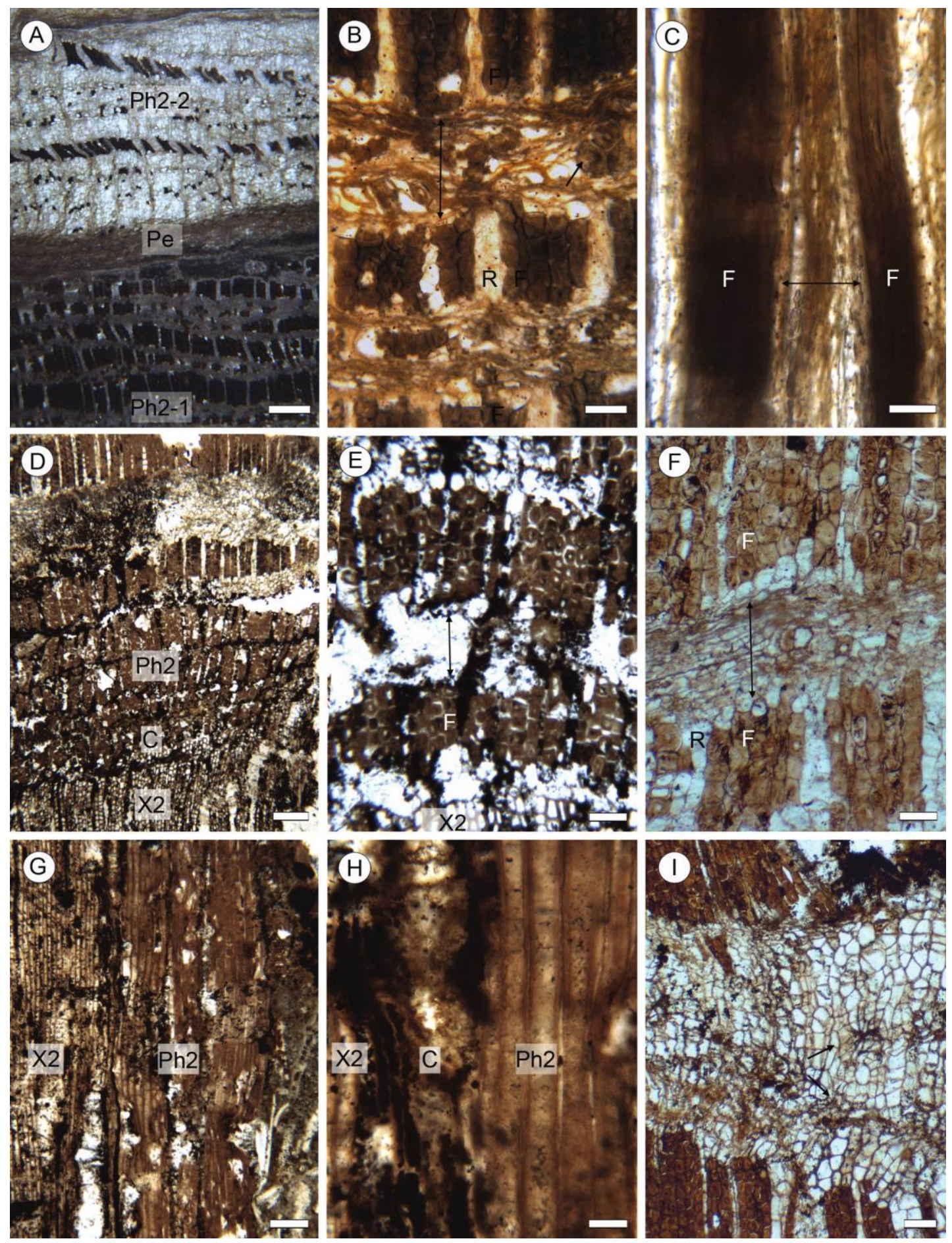

Fig. 6 Secondary phloem anatomy in two unnamed Early Mississippian taxa from Australia $(A-C)$ and Algeria $(D-I)$. A, General view in transverse section of the bark showing the innermost secondary phloem right after the cambium $(\mathrm{Ph} 2-1)$ with conspicuous tangential layers of fibers, a layer of periderm $(\mathrm{Pe})$, and a zone of older phloem (Ph2-2) with a proliferation of axial parenchyma. USNM553730-H-CT2. B, Detail of the Ph21 zone of $A$ showing the successive layers of fibers and crushed thin-walled cells (double-headed arrow). Thick-walled cells are also present within the layer of thin-walled cells (arrow). USNM553730-A-CT1. C, Longitudinal section of the Ph2-1 zone showing the successive layers of fibers and thin-walled cells (sieve cells plus axial parenchyma; double-headed arrow). USNM553727-A-CL1 $\beta$. D, General view in transverse section of the outermost secondary xylem, cambium zone (not preserved), and part of the secondary phloem with alternate layers of fibers and thin-walled 
(1969) as having a simple, parenchymatous secondary phloem, while Solms-Laubach (1893) reported the presence of alternating layers of "stone cells" (i.e., sclereids) separated by thinwalled cells.

\section{Late Carboniferous-Permian Seed Plants}

Secondary phloem anatomy has been documented in detail in several iconic Late Carboniferous taxa, partly thanks to the exceptional preservation of seed plants from the tropical zone in coal-ball deposits of Euramerica. The relatively small climbing or scrambling pteridosperms Lyginopteris and Heterangium (Lyginopteridales) share a secondary phloem composed only of sieve cells and parenchyma (Williamson and Scott 1895; Hall 1952). The sieve cells are produced in unicellular tangential layers that alternate with the axial parenchyma cells in an organization very similar to that of the Mississippian Calamopityales. In Callistophyton (Callistophytales), the organization is comparable, but the layers of parenchyma also contain secretory cells (Bertrand 1889; Russin 1981; Smoot $1984 b$ ). In the older phloem, some parenchyma cells have thickened walls, and rays are enlarged. A similar composition and organization is found in Schopfiastrum (Rothwell and Taylor 1972) and Rhetinangium (Gordon 1912).

Secondary phloem anatomy has also been described in representatives of the Medullosales, a Carboniferous-Permian group of seed plants that includes about 15 species ranging in growth architecture from lianescent to small trees. Work by Smoot (1984a) on the genus Medullosa showed that in the species M. anglica, M. endocentrica, and M. noei the functional secondary phloem contains fibers in addition to the sieve cells and parenchyma. The tissue is organized in repeated one-cellthick tangential layers of sieve cells, fibers, axial parenchyma, sieve cells, fibers, and so on (S-F-P). Old phloem tissue is characterized by the partial or complete collapse of the sieve cells, which results in an increased proportion of fibers. Smoot (1984a) notes that the apparent lack of fibers in some specimens of M. endocentrica and M. pandurata described by Baxter (1949) and Stewart (1951) could reflect taxonomical or developmental differences. In the slightly older vine-like Medullosa stenii described since Smoot's article (Dunn et al. $2003 a$ ), the secondary phloem is composed only of sieve cells and parenchyma and lacks fibers.

The Cordaitales are an extinct group of gymnosperms considered to be closely related or potentially ancestral to the conifers (e.g., Rothwell 1988; Hilton and Bateman 2006). The group includes plants of Carboniferous and Permian age with various growth architecture, ranging from shrubs to large trees. Specimens of Cordaixylon (stems) and Amyelon (roots) studied in detail by Taylor (1988) show an alternation of multicellular layers of sieve cells and layers of axial parenchyma. In the older phloem, the axial parenchyma cells are enlarged, which increases the distance between the layers of sieve cells. Taylor (1988) reviewed previous descriptions of secondary phloem in Carboniferous Cordaitales and concluded that reports of fibers in Amyelon roots (Cridland 1964) and "resinous tubes" in stems of Mesoxylon (Scott 1912, 1918) might in fact correspond to sieve cells in a nonfunctional state. More recently described taxa of Permian age, such as Shanxioxylon sinensis (Wang et al. 2003), apparently had fibers. In transverse section of the inner part of the secondary phloem, the fibers form tangential layers that are one cell thick and alternate with layers of thin-walled cells and sieve cells that are two to four cells thick.

Taxa with and without fibers are thus present, sometimes within a same group, as in the Cordaitales or in the genus Medullosa. Examples of taxa with very thick fiber layers, such as the Australian and Algerian Mississippian taxa described in this article, are missing for the Late Carboniferous-Permian period.

\section{Anatomical Models for Devonian-Carboniferous Secondary Phloem Anatomy (Table 1; Fig. 7)}

The different types of phloem cells tend to be arranged in successive tangential layers in all documented lignophyte taxa of Devonian and Carboniferous age except in the oldest group, the aneurophytalean progymnosperms. This can be interpreted as a lack of tangential organization in this group, indicating that this character evolved later in lignophyte history. However, this conclusion must be taken with caution. The amount of secondary phloem tissue present in axes of the Aneurophytales is typically limited to a few cells (Beck 1957; Scheckler and Banks 1971a, 1971b; Stein and Beck 1983). In some extant conifers, tangential layers of cells do not develop in the youngest phloem, even though the elements that comprise a repetitious sequence can be recognized in each cell file (e.g., Grillos and Smith 1959). A similar phenomenon is observed in some fossils, for example, in Callixylon (Decombeix and MeyerBerthaud 2013) and Stanwoodia (Galtier and Scott 1991; this article), where tangential layers of fibers are conspicuous only in older phloem. The organization of the innermost rows of secondary phloem cells in these taxa cannot be distinguished from that of the Aneurophytales. In the current stage of our knowledge on aneurophytalean anatomy, we thus propose to assign their secondary phloem organization to a distinct model (model A; see below) but do not exclude the possibility that further work on the group will lead to their assignment to another model (C).

For the Archaeopteridales and Carboniferous seed plants, we propose to distinguish three general models of secondary phloem anatomy based on the presence/absence and spatial distribution of fibers. This choice is founded on two main points. First, fiber presence and distribution are characteristic

cells. JC874-A1i01. E, Detail of the inner part of the secondary phloem shown in D, with alternate layers of fibers and thin-walled cells (doubleheaded arrow). JC874-A1i01. F, Detail of the outer part of the secondary phloem showing a layer of crushed thin-walled cells between two layers of fibers. JC874-A1i01. G, General view in radial section showing the outermost secondary xylem and the secondary phloem with fibers. JC874B2L1. H, Detail of the cambium zone. JC874-B2L1. I, Transverse section in the old phloem in a zone with proliferation of thin-walled cells that might indicate the initiation of a periderm layer. JC874-A1i01. $\mathrm{C}=$ cambium zone, $\mathrm{F}=$ fiber, $\mathrm{R}=$ ray, $\mathrm{X} 2=$ secondary xylem. $\mathrm{Scale}$ bars: $A=$ $500 \mu \mathrm{m} ; B, C, E, F, I=100 \mu \mathrm{m} ; D, G=250 \mu \mathrm{m} ; H=50 \mu \mathrm{m}$. 
Table 1

Progymnosperm and Seed Plant Taxa with Preserved Secondary Phloem Discussed in This Article

\begin{tabular}{|c|c|c|c|c|}
\hline Genus & $\begin{array}{c}\text { Alternate } \\
\text { tangential } \\
\text { layers }\end{array}$ & $\begin{array}{l}\text { Fibers in } \\
\text { inner } \mathrm{Ph} 2\end{array}$ & Model & Reference(s) \\
\hline \multicolumn{5}{|l|}{ Late Devonian, progymnosperms: } \\
\hline Protekoalon (Aneurophytales) & - & + & A & Scheckler and Banks $1971 b$ \\
\hline Tetraxylopteris (Aneurophytales) & - & + & A & Beck 1957 \\
\hline Triloboxylon (Aneurophytales) & - & + & A & Stein and Beck 1983 \\
\hline Callixylon (Archaeopteridales) & + & - & B & Arnold 1930a, 1930b; Lemoigne et al. 1983 \\
\hline Callixylon (Archaeopteridales) & + & + & $\mathrm{C}$ & 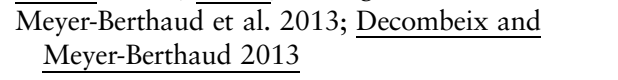 \\
\hline \multicolumn{5}{|l|}{ Mississippian, seed plants: } \\
\hline Calamopitys (Calamopityales) ${ }^{a}$ & + & - & B & Galtier and Hébant 1973 \\
\hline Diichnia (Calamopityales) & + & - & B & Beck et al. 1992 \\
\hline Triichnia (Calamopityales) & + & - & B & Galtier and Beck 1992 \\
\hline Galtiera (Calamopityales) & + & - & B & Beck and Stein 1987 \\
\hline Bostonia (Calamopityales) & + & - & B & Stein and Beck 1978 \\
\hline Lyginopitys (incertae sedis) ${ }^{\mathrm{a}}$ & + & + & $\mathrm{C}$ & Galtier 1970 \\
\hline Faironia (incertae sedis) ${ }^{\mathrm{a}}$ & + & + & $\mathrm{C}$ & Decombeix et al. 2006 \\
\hline Eristophyton (incertae sedis) ${ }^{\mathrm{a}}$ & + & + & $\mathrm{C}$ & Galtier et al. 1993; Galtier and Scott 1994 \\
\hline Bilignea $\left(\right.$ incertae sedis) ${ }^{\mathrm{a}}$ & + & + & $\mathrm{C}$ & Galtier et al. 1993 \\
\hline Stanwoodia (incertae sedis) ${ }^{\mathrm{a}}$ & + & + & $\mathrm{C}$ & Galtier and Scott 1991 \\
\hline Australian taxon (incertae sedis) ${ }^{a}$ & + & $+^{\mathrm{b}}$ & $\mathrm{D}$ & Decombeix 2013 \\
\hline Algerian taxon (incertae sedis) $^{\mathrm{a}}$ & + & $+^{\mathrm{b}}$ & $\mathrm{D}$ & Galtier and Meyer-Berthaud 2006 \\
\hline Trivena (Lyginopteridales) & + & & & Dunn et al. 2003b; Dunn 2006 \\
\hline Medullosa (Medullosales) & + & - & B & Dunn et al. $2003 a$ (M. steinii) \\
\hline \multicolumn{5}{|l|}{ Pennsylvanian-Permian, seed plants: } \\
\hline Medullosa (Medullosales) & + & + & $\mathrm{C}$ & $\begin{array}{l}\text { Delevoryas 1955; Smoot } 1984 a \\
\quad \text { endocentrica, and M. noei) }\end{array}$ \\
\hline Lyginopteris (Lyginopteridales) & + & - & B & Williamson and Scott 1895 \\
\hline Heterangium (Lyginopteridales) & + & - & B & Hall 1952 \\
\hline Rhetinangium (Lyginopteridales) & + & - & B & Gordon 1912 \\
\hline Microspermatopteris (Lyginopteridales) & + & - & B & Taylor and Stockey 1976 \\
\hline Schopfiastrum (Lyginopteridales) & + & - & B & Rothwell and Taylor 1972; Stidd and Phillips 1973 \\
\hline Callistophyton (Callistophytales) & + & - & B & Bertrand 1889; Russin 1981; $\underline{\text { Smoot } 1984 b}$ \\
\hline Cordaixylon (Cordaitales) & + & - & B & Taylor 1988 \\
\hline Amyelon (Cordaitales) & + & - & B & $\overline{\text { Taylor } 1988}$ \\
\hline Amyelon (Cordaitales) & + & + & $\mathrm{C}$ & Cridland 1964 \\
\hline Mesoxylon (Cordaitales) & + & - & B & Scott 1912, 1918 \\
\hline Shanxioxylon (Cordaitales) & + & + & $\mathrm{C}$ & Wang et al. 2003 \\
\hline
\end{tabular}

Note. Underscored references indicate articles focused on secondary phloem or bark anatomy. See the text for explanations of the different models. $\mathrm{Ph} 2=$ secondary phloem.

a Taxa for which secondary phloem anatomy is described and illustrated in this article.

b Thick layers.

for some extant taxa and considered an important taxonomic element by a majority of authors (e.g., Liu and Gao 1993; Oskolski et al. 2007; Kotina et al 2012 and references in these articles). Second, fibers are usually the best preserved and most conspicuous elements in fossil phloem, so their distribution cannot be subject to as many doubts as can be the case with thin-walled cells, especially sieve cells. Even in extant plants, the distinction between axial parenchyma and sieve cells is sometimes uncertain, especially due to the common collapse of the latter as the phloem ages. Significant studies of secondary phloem in extant seed plants have also focused on the distribution of so-called mechanical components of the secondary phloem (fibers and sclereids $=$ thick-walled cells) to elaborate models (e.g., Den Outer 1967, 1993; Furuno 1990 and references in these articles). This makes the comparison with our fossil data easier. Table 2 summarizes the characteristic of each model and shows the correspondence with Den Outer's types for extant gymnosperms. Figure 7 illustrates representatives of our four models and allows their straightforward comparison. The alphabetical order of the models for the fossil plants does not imply an evolutionary trend.

\section{Model A}

The different cell types are not arranged in repeated tangential layers. The secondary phloem contains fibers, parenchyma, sieve cells, sclereids, and secretory cells. This organization is found in the aneurophytalean progymnosperms of the Devonian, the oldest plants with secondary phloem.

\section{Model B}

The different cell types are arranged in repeated tangential layers. The secondary phloem tissue does not contain fibers; 
the axial system contains only parenchyma and sieve cells, plus secretory cells in some taxa and occasional sclereids. This type of organization is found in the Mississippian seed plant Calamopitys and is also apparently present in affiliated taxa, such as Diichnia (Beck et al. 1992), Triichnia (Galtier and Beck 1992), Galtiera (Beck and Stein 1987), and Bostonia (Stein and Beck 1978). In the latter two taxa, sclereids are reported. Among younger Carboniferous taxa, this organization is also found in Lyginopteris (Williamson and Scott 1895), Heterangium (Hall 1952), Callistophyton (Russin 1981; Smoot 1984b), Schopfiastrum (Rothwell and Taylor 1972), Rhetinangium (Gordon 1912), some Medullosales (Dunn et al. 2003a), and some Cordaitales (Taylor 1988). This type of organization has been reported by some authors (Arnold 1930a; Lemoigne et al. 1983) in Late Devonian axes of the progymnosperm Callixylon/Archaeopteris from North America and Siberia. In extant gymnosperms, it is found in the conifer family Pinaceae (e.g., Chang 1954; Den Outer 1967).

\section{Model C}

The different cell types are arranged in repeated tangential layers. The secondary phloem contains fibers that form more or less continuous tangential layers that are one to two cells in radial thickness. In addition, the axial system contains parenchyma, sieve cells and in some cases secretory cells, and/or occasional sclereids. This type of organization is found in the Mississippian seed plants Lyginopitys, Eristophyton, Stanwoodia, Bilignea, and possibly Faironia. Among younger Carboniferous-Permian taxa, it is also found in some Medullosales (Smoot 1984a) and some Cordaitales (Wang et al. 2003). A similar organization has been recently described in stems and roots of the progymnosperm Callixylon/Archaeopteris from the Late Devonian of Morrocco (Decombeix and MeyerBerthaud 2013; Meyer-Berthaud et al. 2013). It is also found in most extant gymnosperms.

Some taxa, such as Callixylon and Stanwoodia, have an interrupted and sometimes irregular distribution of the fibers, while others, such as Bilignea and Lyginopitys, have a much more continuous arrangement of fibers.

\section{Model D}

The different cell types are arranged in repeated tangential layers. The secondary phloem contains conspicuous multicellular layers of fibers (often up to eight to nine cells thick). In addition, the axial system contains multicellular layers of parenchyma, sieve cells and in some cases secretory cells, and/or occasional sclereids. This model is observed in two early Mississippian taxa, one from Australia and one from Algeria. To the extent of our knowledge, it has not been reported in any other fossil seed plant and does not occur in extant gymnosperms. A similar arrangement of fibers is, however, common in extant angiosperms, such as Liriodendron and Tilia (e.g., Esau 1969).

\section{Secondary Phloem Anatomy and the Mississippian Diversification of Seed Plants}

Documenting these various secondary phloem anatomies present in Mississippian seed plants provides additional char- acters to evaluate their taxonomic diversity. Among extant gymnosperms, characters of bark anatomy are usually constant within a genus (e.g., Chang 1954) and have been used in taxonomy, although to a much smaller extent than secondary xylem characters. A good example of the utility of bark anatomy among the Mississippian taxa is that of the Australian trees mentioned in this article. Although they have a wood very similar to the European taxa Pitus and Eristophyton, their distinct bark anatomy supports previous observations of poorly preserved primary structures that they in fact represent a different genus (Decombeix et al. 2011b; Decombeix 2013).

Data on the Mississippian seed plants combined with the review of our knowledge of older (Devonian) and younger (Pennsylvanian) lignophytes show that the Mississippian corresponds to a period of diversification of secondary phloem anatomy (table 1; fig. 7). Studies of extant angiosperms show that the evolution of secondary xylem characters in this group has been remarkably influenced by the evolution of new growth architectures and the occupation of new habitats (e.g., Baas et al. 2003; Carlquist 2013; Pace and Angyalossy 2013 and references in these articles). There is little doubt that similar phenomena can explain the anatomical diversification observed in the vascular system of their ancestors between the Late Devonian and Early Carboniferous.

The development of various growth architectures, from shrubby plants to potentially climbing ones to large trees, implies an adaptation of the vascular systems to various constraints in the transport of water and photosynthates across the plant body. In the case of the Early Carboniferous seed plants, these constraints might have also been enhanced by the diversification of the size and shape of the megaphyllous leaves (Galtier 2010). Among extant plants, a correlation between growth architecture and secondary phloem anatomy has been documented in some cases. While all these studies have been of angiosperms, they suggest possible trends that agree with what is observed in the fossils. Den Outer (1993) studied 463 African species from 31 families of angiosperms with various growth architectures (tree, shrub, and climber) and habitats (rain forest and savannah). He showed differences between climbers and trees and rain forest and savannah with regard to the three different types of secondary phloem that he recognized: Tilia (thick layers of fibers), Populus (one-cell layers of fibers), and Datura (isolated sclereids, no fibers). The last type was more common in climbers than in trees, which he interpreted as a focus on transport versus mechanical support. This trend is quite comparable to what is known in the secondary xylem of climbing plants, characterized by vessels with a larger diameter than closely related trees (e.g., Ewers 1985). The simplest organization of the secondary phloem in Mississippian seed plants is the one found in Calamopitys. These plants, which have been reconstructed as non-self-supporting, tend to have long internodes and large petiole bases; their xylem is characterized by tracheids with a very large diameter, another character found in extant climbing plants (Galtier 1974; Rowe et al 1993). The secondary phloem is of model $\mathrm{B}$, composed of elements with a role in conduction and storage but no so-called mechanical elements (fibers or sclereids). It must be noted that some related taxa, such Galtiera (Beck and Stein 1987) and 

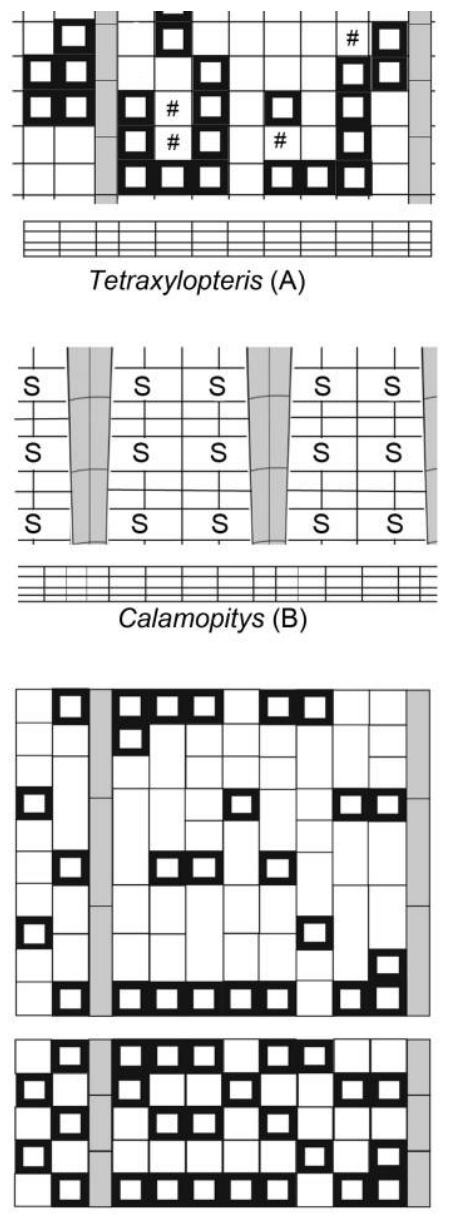

Callixylon (C)

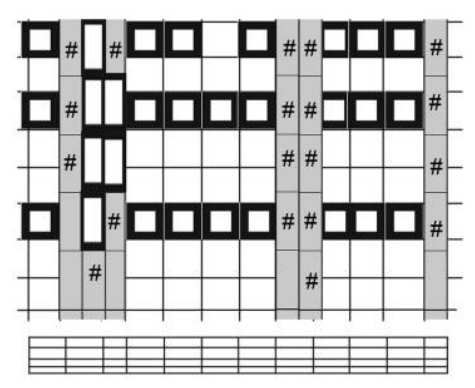

Lyginopitys (C)

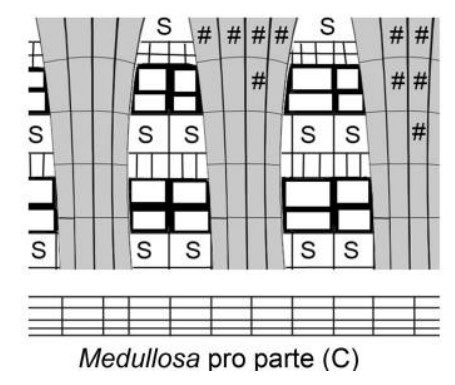

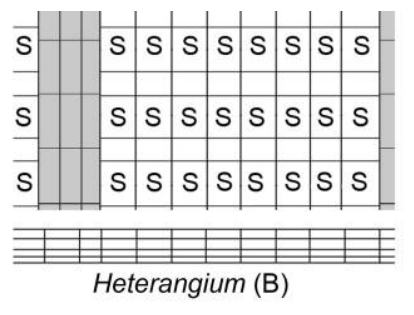
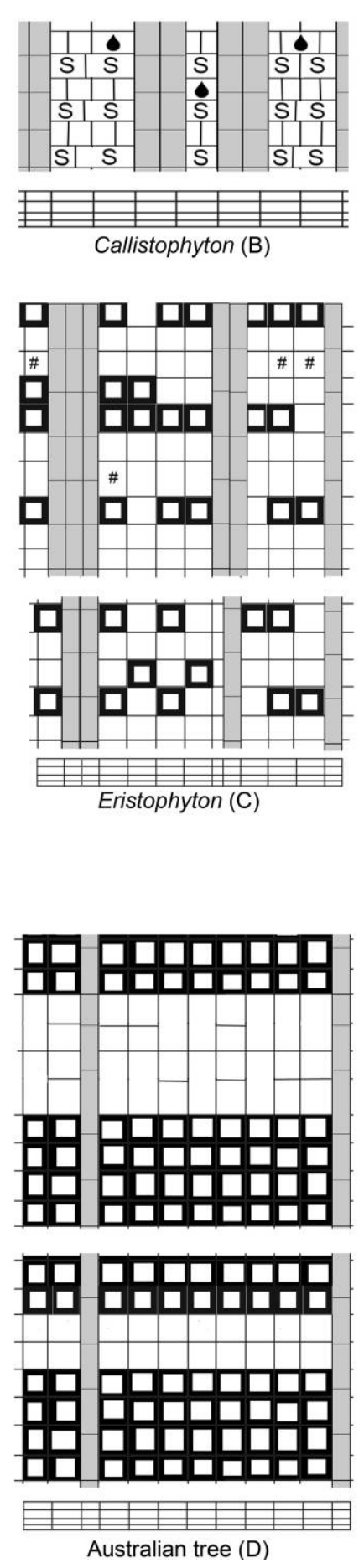
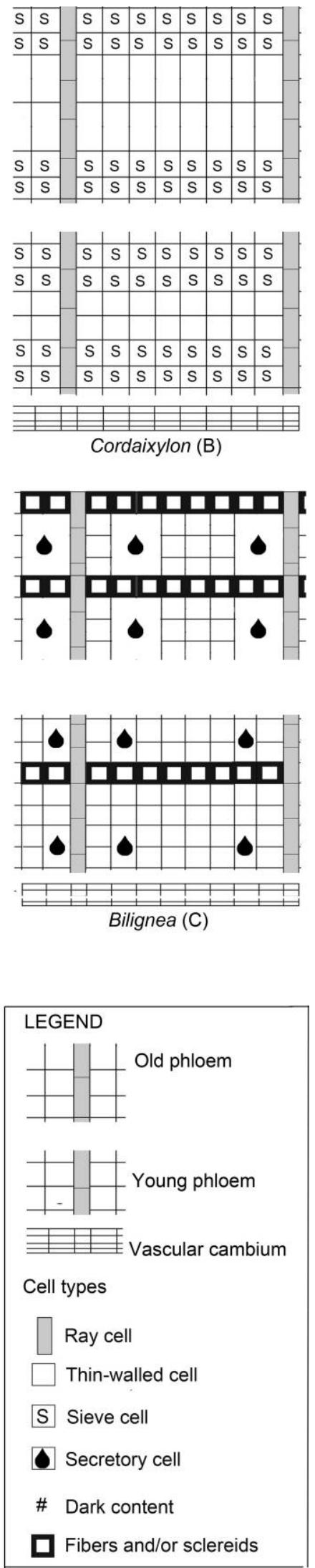
Bostonia (Stein and Beck 1978), have mechanical elements in the form of sclereids; however, their growth architecture is not well known. Mississippian taxa with fibers in their secondary phloem (models C and D) are mostly trees (e.g., Eristophyton, Australian taxa) or taxa for which growth architecture is unknown (e.g., Lyginopitys).

In addition to the diversification of their growth forms, the evolution during the Late Devonian of the seed habit allowed lignophyte plants to become independent from water for their reproduction and potentially capable of colonizing new habitats compared with the Devonian progymnosperms. Although the oldest definite evidence for upland floras is documented in the Pennsylvanian (Falcon-Lang and Bashforth 2004 and references therein), there is good anatomical and depositional evidence that some Mississippian seed plants could grow in volcanic settings and in environments with periodic water stress (e.g., Galtier and Scott 1994; Scott and Galtier 1996; Galtier et al. 1998; Falcon-Lang 1999; Decombeix et al. $2011 b$; Henderson and Falcon-Lang 2011). Their vegetative body had to adapt to dryer, more irregular conditions, and this is especially true in long-lived plants that take several years to reach reproductive maturity (Petit and Hampe 2006). In that context, it is important that secondary phloem tissues can interact with living components of the xylem to repair embolism (e.g., Salleo et al. 1996; Zwieniecky et al. 2004 and references therein). In addition, phloem parenchyma provides potential storage locations for carbohydrates that are distributed all along the plant body. Components of old secondary phloem are also known in extant plants to protect the cambium from herbivores. This protection can be either mechanical, such as tangential layers of fibers or sclereids, or chemical, that is, by storage in the phloem parenchyma of repelling compounds, such as phenols or alkaloids (e.g., Franceschi et al. 1998). While a role in osmotic exchanges is impossible to detect in the fossils, the occurrence in the Mississippian seed plants of such characters as a proliferation of parenchyma in the old phloem (e.g., Callixylon, Stanwoodia), thick tangential layers of fibers (e.g., Australian taxa), and secretory structures (e.g., Bilignea) suggest adaptations to storage and protection comparable to extant taxa.

\section{Is It Possible to Detect Trends in Secondary Phloem Early Evolution?}

Because preservation of secondary phloem is rare in the fossil record, the great majority of studies of the evolution of this tissue are based on extant gymnosperms and angiosperms only. However, the available data on Devonian and Carboniferous taxa allow us to compare these studies with fossil data.

\section{Organization of the Secondary Phloem in Repeated Tangential Layers}

Botanists studying the secondary phloem of extant seed plants have noted for a long time that in both conifers and dicotyledonous angiosperms this tissue tended to be organized in repeated tangential layers of a similar cell type (Esau 1969). Den Outer (1967) studied the secondary phloem anatomy of gymnosperms and distinguished three types of phloem organization (table 2). In the Pseudotsuga type, the secondary phloem consists mostly of sieve cells, with a few parenchyma cells that can either form discontinuous tangential layers or be scattered among the sieve cells. In this type, phloem fibers are totally lacking. Some taxa are completely devoid of sclerenchymatous cells (e.g., Pinus sylvestris), while in others sclereids can be formed by the thickening of axial parenchyma cells; in some cases, stone cell nests are formed in the older part of the phloem. This model is similar to our model B by the absence of fibers but differs from it by including taxa with no regular arrangement in tangential layers of the other cell types (sieve cells and axial parenchyma). No example of a Pseudotsugalike type of secondary phloem is thus currently known in early lignophytes of Devonian-Carboniferous age (table 1).

The second type recognized by Den Outer (1967) is the Ginkgo biloba type, characterized by alternating tangential layers of sieve cells and axial parenchyma. In Ginkgo, layers of parenchyma one to three cells thick alternate with layers of sieve cells one to two cells thick; a few isolated fibers occur within the parenchyma layers, including in the inner phloem. In other taxa, such as Podocarpus nerifolius, tangential layers of fibers can occur; they are sometimes absent or interrupted by parenchyma. In addition to Ginkgo, Den Outer includes in this type all members of the Cycadaceae and Araucariaceae as well as some taxa belonging to the Podocarpaceae and Taxaceae. The Ginkgo type of Den Outer is comparable to our models B (alternating layers, no fibers) and C (alternating layers, some fibers). Among the taxa with fibers, some taxa, such as Callixylon and Stanwoodia, have an interrupted and sometimes irregular distribution of fibers, while others, such as $B i$ lignea and Lyginopitys, have a much more regular arrangement of fibers (fig. 7).

Finally, the third organization recognized in gymnosperms by Den Outer is the Chamaecyparis pisifera type. In these taxa, the secondary phloem is formed of regularly alternating tangential layers of parenchyma cells, sieve cells, phloem fibers, sieve cells, parenchyma cells, and so on (P-S-F-S). Layers of fibers can be several cells in thickness, especially at the end of the growth season. In some cases, they can also be in part replaced by parenchyma. Because of the often poor preser-

Fig. 7 Schematic drawings of secondary phloem anatomy in transverse section for some representative genera of Devonian-Permian lignophytes showing the different cell types recognized and their arrangement. The corresponding model (see "Anatomical Models for Devonian-Carboniferous Secondary Phloem Anatomy" in the text) is indicated in parentheses for each taxon. Sieve cells have been indicated only for taxa in which their location has been precisely identified. In taxa where the distinction between sieve cells and axial parenchyma has not been made with confidence, both types of cells are represented by the thin-walled cell symbol. For taxa with a significant amount of secondary phloem, the changes occurring in the old parts of the tissue are also illustrated: dilatation of axial parenchyma cells in Cordaixylon, dilatation of axial parenchyma cells with mostly periclinal divisions and crushing of sieve cells in Callixylon, crushing of sieve cells and dilatation of rays in Eristophyton, conspicuous enlargement of secretory cells and crushing of other thin-walled cells in Bilignea, and dilatation of axial parenchyma cells with mostly periclinal divisions and crushing of sieve cells in the Australian taxa. See table 1 for taxa ages and references. 
Table 2

Correspondence between the Models of Secondary Phloem Anatomy Proposed by Den Outer (1967) for Extant Gymnosperms and the Models Proposed in This Article for Devonian and Carboniferous Lignophytes

\begin{tabular}{lll}
\hline Fibers & No tangential layers & \multicolumn{1}{c}{ Tangential layers } \\
\hline None & DO: Pseudotsuga type & $\begin{array}{l}\text { DO: Ginkgo type } \\
\text { F: model B }\end{array}$ \\
Dispersed or one- to two-cell-thick layers & F: model A & $\begin{array}{l}\text { DO: Ginkgo type and Chamaecyparis type } \\
\text { F: model C }\end{array}$ \\
Thick layers up to eight or nine fibers & & F: model D \\
\hline
\end{tabular}

Note. $\quad$ DO $=$ Den Outer types based on extant gymnosperms, $\mathrm{F}=$ models based on fossils described in this article.

vation of the sieve cells in the fossils, it is often difficult to determine their position within layers of thin-walled cells and thus to compare the fossils to the Chamaecyparis pisifera type of Den Outer. One fossil belonging to our model C for which all types of cells have been clearly identified is Medullosa (Smoot 1984a), where the sequence of cell types is slightly simpler than in Chamaecyparis: axial parenchyma/sieve cell/ fiber (P-S-F) instead of parenchyma/sieve cell/fiber/sieve cell (P-S-F-S). In the case of the Mississippian Lyginopitys, we observed in the inner part of the phloem an organization that seems to be of the P-S-F-S type. However, unlike in extant conifers with this organization, the layers do not appear to be constantly one cell thick; for example, there are at least two parenchyma cells in the parenchyma layer.

An important trend proposed by Den Outer for gymnosperm secondary phloem is a change from a type mostly composed of sieve cells with rare axial parenchyma (Pseudotsuga) to a type with a regular sequence of tangential layers of different cell types (Chamaecyparis), with a general increase in the amount of axial parenchyma and decrease in the number of sieve cells. This is interpreted as a change from a phloem tissue with almost no differentiation of function to a tissue with welldifferentiated cell functions. Hypotheses to explain this change are usually related to better communication between the different cell types (Den Outer 1967; Taylor 1990).

Comparison of Den Outer's (1967) hypothetical evolutionary trend based on the observation of extant gymnosperms with fossil evidence shows that the situation is more complex (table 2). The oldest type of secondary phloem, as found in the oldest progymnosperms (model A), does not consist mainly of sieve cells with scattered axial parenchyma but rather includes other types of cells in higher proportion than sieve cells (see fig. 7, Tetraxylopteris). Devonian Archaeopteridales show a strong tendency to have cell types organized in tangential layers (see fig. 7, Callixylon). In the Early Carboniferous and Late Carboniferous seed plants, alternating layers are present in all observed taxa (fig. 7, all other taxa). Thus, none of these early representatives of the lignophytes correspond to the supposedly primitive type of Den Outer. In addition, it must be noted that some other fossils show patterns that are not observed in extant gymnosperms and thus do not correspond to any of Den Outer's models. This is the case with the very thick layers of fibers found in the Mississippian trees from Australia and Algeria illustrated in this article (model D; fig. 7, "Australian tree"). Unlike in extant gymnosperms, where layers of fibers several cells thick are rare, it is the normal situation in those fossils. Another example that has, to our knowledge, no extant equivalent in gymnosperms is the alternation of onecell-thick layers of fibers and sieve cells seen in the Mesozoic Bennettitales (Ryberg et al. 2007).

Among angiosperms, repeated layers of a same cell type occur in the secondary phloem of many dicotyledon species, with sequences more complex, however, than in the gymnosperms (e.g., Esau 1969; Barlow and Lück 2005). While secondary phloem anatomy in fossil angiosperms remains mostly unknown, the data on gymnosperms and progymnosperms presented here warrants caution regarding "primitive" versus "derived" organizations of angiosperm phloem.

\section{Presence and Distribution of Sclereids and Fibers}

Sclereids are formed by the thickening of axial parenchyma in the old phloem and generate a late mechanical strengthening system, whereas fibers are formed as part of the functional phloem and generate an early, more or less spatially organized strengthening system (Esau 1969). Another trend hypothesized by Den Outer (1967) on the basis of the observation of extant gymnosperms is the change from taxa with only sclereids to (1) taxa with sclereids and dispersed phloem fibers, (2) taxa with only dispersed fibers, and (3) taxa with regular tangential layers of fibers. The fossil record shows, however, that in the oldest taxa with secondary phloem, fibers are already present in the innermost functional phloem. This is the case for the Devonian progymnosperms, both in the Aneurophytales (model A) and in at least some Archaeopteridales (model C; table 1; fig. 7). In the latter, the fibers tend to be organized in tangential layers, the last evolutionary step, according to Den Outer. Thus, it appears that the presence of fibers might in fact be a primitive character of the secondary phloem. Among the Early Carboniferous taxa, several organizations are found (table 1; fig. 7): (1) taxa devoid of fibers and sclereids, such as Calamopitys (model B); (2) taxa with some sclereids (Bostonia, model B); (3) taxa with fibers that tend to be organized in tangential rows (e.g., Eristophyton, model C); (4) taxa with uninterrupted tangential rows of fibers (e.g., Bilignea, model $\mathrm{C})$; and (5) taxa with repeated multicellular layers of fibers (model D; new taxa of Decombeix 2013 and of this article). A summary observation of Devonian and Carboniferous lignophyte taxa for which secondary phloem is known suggests that, apart from the basalmost Aneurophytales, the presence of fibers might be linked to the habit of the plants, a trend that is observed in some groups of extant angiosperms. Carboniferous taxa that have been reconstructed as non-self-supporting (i.e., lianescent or scrambling) tend to lack fibers. In 
addition to the previously mentioned Mississippian Calamopityaceae, this is the case, for example, for the Pennsylvanian Lyginopteris (Williamson and Scott 1895), Heterangium (Hall 1952), and Callistophyton (Bertrand 1889; Russin 1981; Smoot 1984b). Inversely, self-supporting (shrubby or arborescent) taxa tend to have fibers. For groups such as the Medullosales or the Cordaitales (Smoot 1984a; Taylor 1988) within which plant species with different growth habits were present, the situation is more complex, as the growth architecture of the taxa for which secondary phloem is known is not always certain. It is, however, interesting to note that the one known taxa of Medullosa with no fibers corresponds to a vine-like plant (Dunn et al. 2003a) and that the specimens of Cordaixylon with no fibers are relatively small stems (Taylor 1988). It is very likely that these various secondary phloem anatomies also reflect ontogenetic variations, for example, with more fibers present in the proximal axes, as was noted in cycads (e.g., Greguss 1968).

\section{Maturation/Changes in Old Phloem}

As the secondary phloem ages and becomes nonfunctional, it undergoes several types of histological changes. Similar changes are also observed in the phloem of Devonian and Carboniferous lignophytes (Smoot 1984a; this article).

A first change occurring as phloem ages affects the sieve cells and conditions the so-called functional (i.e., conducting) versus nonfunctional state of the tissue. According to the literature, in most seed plant species only the youngest increment of secondary phloem tissue (deciduous dicotyledons) or the last two increments (evergreen dicotyledons and conifers) are functional (Esau 1969 and references therein). In some species, the sieve areas of the cells produced in a given growth season are occluded by callose deposits and can become functional again the second season (the "reactivation" of Esau 1948). In some angiosperms, however, sieve elements can remain functional for several years-up to 10 in Tilia, for example (Holdheide 1951). It is also important to keep in mind that the great majority of extant species that have been studied grow in temperate regions. In his study of the bark anatomy of dipterocarps, Whitmore $(1962 a, 1962 b)$ calculated that the conducting life of the phloem in two species of the genus Shorea growing in a nonseasonal climate was around $11 \mathrm{yr}$ at least. On the other hand, some tropical species have sieve cells that function for only one season (e.g., Ghouse and Hashmi 1980). Sieve cells/tubes that are nonfunctional can remain similar in aspect (except for the callose deposits), become thickened, or completely collapse, depending on the taxa. Because of these variations documented in extant plants, it is difficult to delimit the functional versus nonfunctional parts of the secondary phloem in fossil plants and measure the amount of tissue that played a role in conduction at a given moment. Collapsing of the sieve cells can be hard to detect if the tissue is distorted during fossilization. The presence of callose deposits-observed, for example, in Medullosa (Smoot 1984a)—is a good clue of a nonfunctional state but is not entirely dependable, given the possibility of a reactivation mechanism similar to that of some extant plants (see above).

Other changes to the cells composing the secondary phloem as it ages are easier to observe in the fossil record. One of these changes is the sclerification of axial or ray parenchyma cells. Unlike sieve cells/tubes, parenchyma cells in old phloem often remain functional and have a role in storage of starch or other material. In some taxa, however, they become sclerified and form isolated sclereids, sclereids nests, or layers of sclereids. In Devonian-Carboniferous fossils, an example is the sclerification of ray cells in Lyginopitys (figs. 2I, 7).

A third, usually very conspicuous change occurring as secondary phloem ages is dilatation (sensu De Bary 1877 and Esau 1969), which corresponds to the increase in size and, in some cases, proliferation of parenchyma cells to adjust to the increase in circumference resulting from the process of secondary growth. Two mechanisms can be distinguished (Whitmore 1962a, 1962b; Esau 1969). The first involves ray parenchyma cells, with an increase in individual cell size and the formation of additional cells via an intercalary tissue. This type of dilatation (termed "ray dilatation" in the remainder of the text) can lead to a considerable enlargement of rays toward the outside of the phloem. This results in the formation of wedges of phloem tissue included between very large rays that are fan shaped in transverse section. The second mechanism is the enlargement and proliferation (via periclinal and/or anticlinal divisions) of axial parenchyma cells (termed "axial parenchyma dilatation" in the remainder of the text). Ray and axial parenchyma dilatation very rarely occur together (e.g., Holdheide 1951; Whitmore 1962a, 1962b; Esau 1969). Among extant conifer taxa, axial parenchyma dilatation is by far the most common, with only rare examples of ray dilatation (Esau 1969).

Interestingly, both dilatation of ray parenchyma and dilatation of axial parenchyma have been observed in Devonian and Carboniferous fossils (fig. 7). These changes tend to be progressive, with no sharp limit observed between the young and old phloem. Plants included in our model A (Aneurophytales) have only a limited amount of secondary phloem and do not show evidence in the known specimens of conspicuous changes as the tissue ages. In our model B (no fibers), there is a significant dilatation of rays toward the outer part of the secondary phloem in almost all known taxa, both Mississippian (e.g., Calamopitys) and Pennsylvanian (e.g., Lyginopteris). Both ray cell enlargement and ray cell anticlinal divisions are observed. One exception is the cordaitean Cordaixylon (Taylor 1988), which shows a dilatation of axial parenchyma cells. In the two taxa belonging to model D (thick layers of fibers), there is a dilatation of axial parenchyma cells in the older phloem, with an enlargement of individual cells and divisions that are mostly periclinal. There is no significant change in ray cell size or number. In model $\mathrm{C}$, changes are very variable between taxa (fig. 7). There is a dilatation of axial parenchyma cells in Callixylon (Devonian) and Stanwoodia (Mississippian). As in the two taxa from model $\mathrm{D}$, axial parenchyma divisions are mostly periclinal, and the tangential enlargement of the tissue is mainly due to the increase in axial parenchyma cell diameter. Dilatation of ray parenchyma, with both cell enlargement and proliferation, is observed in Eristophyton, Lyginopitys (Mississippian), and Medullosa (Pennsylvanian). In Bilignea (Mississippian), there is a conspicuous enlargement of the secretory structures that is reminiscent of the enlargement of resin canals observed in some extant conifers (Esau 1969). It is likely that these different strategies reflect an ad- 
aptation of the tissue to different functions (such as storage, mechanical strengthening, and physical or chemical defense) as the conductive elements became occluded and no longer functional. This change in function of the tissue is obtained by a combination of changes to individual cell characteristics (e.g., enlargement, thickening of the walls) and changes in the proportion of the different cells types (e.g., occlusion, division). Axial parenchyma dilatation in the Devonian progymnosperm Callixylon is to date the oldest known type of adaptation to an increase in stem circumference.

\section{Conclusions and Remaining Questions}

Mississippian seed plants with preserved secondary phloem show a significant diversity in the composition and organization of this tissue. When added to a synthesis of previous studies of Devonian progymnosperms and younger seed plants of Pennsylvanian age, these data highlight the existence of a Mississippian diversification in lignophyte secondary phloem anatomy that parallels what is observed for other parts of the vascular system of these plants (primary and secondary xylem). This is probably linked to the diversification of growth architectures, leaf sizes, and possibly habitats in seed plants at that time.

From the viewpoint of secondary phloem evolution, we show that characters considered advanced on the basis of the study of extant plants appeared early in lignophyte evolution. The presence of fibers in the functional phloem already existed in progymnosperms and is also found in many seed plant taxa of Mississippian and Pennsylvanian age. Similarly, the arrangement of the secondary phloem tissue in repeated tangential layers is already found in some Devonian progymnosperms and occurs in all Carboniferous seed plants. The different changes linked to maturation observed in extant plants are represented in Mississippian seed plants. Interestingly, at least one type of organization seen in the Mississippian taxa is unknown in other fossil or extant gymnosperms.

While secondary phloem anatomy can, in some cases, be well preserved in fossils, it is still undocumented in a certain number of taxonomically important taxa, which strongly limits the possibility to fully understand the evolution of this tissue. Secondary phloem anatomy remains unknown (or possibly did not develop) in seed plants of Late Devonian age, preventing any assessment of the tissue organization in the oldest representatives of this group. Most early conifers and ginkgos are described on the basis of decorticated stems for which secondary phloem information is missing. Secondary phloem anatomy is also not documented in several significant extinct groups, including (1) the Glossopteridales, which dominated Permian floras of Gondwana; (2) the Gigantopteridales, which had a secondary xylem with vessels; and (3) all Mesozoic seed ferns that are considered to be possible close relatives to the angiosperms, such as the Caytoniales. Finally, there are extremely few data on secondary phloem anatomy in fossil angiosperms of any age. It is our opinion that an increased search for specimens with preserved secondary phloem would lead to significant findings, not only in terms of the evolution of this tissue but also for fossil plant diversity, taxonomic relationships, and physiology.

\section{Acknowledgments}

This work was partly funded by the French National Agency for Research (project ANR TERRES 2010 BLAN 607 02). Comments on the manuscript by W. Stein, an anonymous reviewer, and the editor, M. Dunn, are gratefully acknowledged. Botany and Computational Plant Architecture (Botanique et Bioinformatique de l'Architecture des Plantes [AMAP]; http:// amap.cirad.fr) is a joint research unit associated with the Centre de Coopération Internationale en Recherche Agronomique pour le Développement (CIRAD; Unité Mixte de Recherche [UMR] 51), Centre National de la Recherche Scientifique (CNRS; UMR5120), Institut National de la Recherche Agronomique (INRA; UMR931), Institut de Recherche pour le Développement (IRD; UMR123), and Montpellier 2 University (UM27).

\section{Literature Cited}

Arnold CA 1930a Bark structure of Callixylon. Bot Gaz 90:427-431. $1930 b$ The genus Callixylon from the Upper Devonian of central and western New York. Pap Mich Acad Sci Arts Lett Pt 1 Bot For 11:1-50

Baas P, S Jansen, EA Wheeler 2003 Ecological adaptations and deep phylogenetic splits: evidence and questions from the secondary xylem. Pages 221-239 in T Stuessy, V Mayer, E Hörandl, eds. Deep morphology: toward a renaissance of morphology in plant systematics. ARG Gantner, Ruggell.

$\rightarrow$ Barlow PW, J Lück 2005 Repetitive cellular patterns in the secondary phloem of conifer and dicot trees, and a hypothesis for their development. Plant Biosyst 139:164-179.

$\rightarrow$ Baxter RW 1949 Some pteridosperm stems and fructifications with particular reference to the Medullosae. Ann Mo Bot Gard 36:287352 .

$\rightarrow$ Beck CB 1957 Tetraxylopteris schmidtii gen. et. sp. nov., a probable pteridosperm precursor from the Devonian of New York. Am J Bot 44:350-367.
1960 Connection between Archaeopteris and Callixylon. Science 131:1524-1525.

2005 An introduction to plant structure and development. Cambridge University Press, Cambridge.

$\rightarrow$ Beck CB, J Galtier, WE Stein Jr 1992 A reinvestigation of Diichnia Read from the New Albany Shale of Kentucky. Rev Palaeobot Palynol 75:1-32.

$\rightarrow$ Beck CB, WE Stein Jr 1987 Galtiera bostonensis, gen. et sp. nov., a protostelic calamopityacean from the New Albany Shale of Kentucky. Can J Bot 65:348-361.

Beck CB, DC Wight 1988 Progymnosperms. Pages 1-84 in CB Beck, ed. Origin and evolution of gymnosperms. Columbia University Press, New York.

Bertrand CE 1889 Les Poroxylons: végétaux fossiles de l'Epoque Houillère. Ann Soc Belg Microsc 13:1-49.

$\rightarrow$ Carlquist S 2013 More woodiness/less woodiness: evolutionary avenues, ontogenetic mechanisms. Int J Plant Sci 174:964-991.

Chang YP 1954 Bark structure of North American conifers. US Dep Agric Tech Bull 1095:1-86. 
Cridland AA 1964 Amyelon in American coal-balls. Palaeontology 7: 186-209.

De Bary A 1877 Vergleichende Anatomie der Vegetationsorgane der Phanerogamen und Farne. Engelmann, Leipzig. (English translation by FO Bower, DH Scott 1884 Clarendon, Oxford.)

$\rightarrow$ Decombeix A-L 2013 Bark anatomy of an Early Carboniferous tree from Australia. IAWA J 34:183-196.

$\rightarrow$ Decombeix A-L, J Galtier, B Meyer-Berthaud 2006 Faironia difasciculata, a new gymnosperm from the Early Carboniferous (Mississippian) of Montagne Noire, France. Rev Palaeobot Palynol 142: 79-92.

$\rightarrow$ Decombeix A-L, B Meyer-Berthaud 2013 A Callixylon (Archaeopteridales, Progymnospermopsida) trunk with preserved secondary phloem from the Late Devonian of Morocco. Am J Bot 100:22192230.

$\rightarrow$ Decombeix A-L, B Meyer-Berthaud, J Galtier 2011a Transitional changes in arborescent lignophytes at the Devonian-Carboniferous boundary. J Geol Soc 168:547-557.

$\rightarrow$ Decombeix A-L, B Meyer-Berthaud, J Galtier, JA Talent, R Mawson $2011 b$ Arborescent lignophytes in the Tournaisian vegetation of Queensland (Australia): palaeoecological and palaeogeographical significance. Palaeogeogr Palaeoclimatol Palaeoecol 301:39-55.

Delevoryas T 1955 The Medullosae-structure and relationships. Palaeontogr Abt B Palaeophytol 97:115-167.

Den Outer RW 1967 Histological investigations of the $2^{\circ}$ phloem in gymnosperms. 1. Introduction. Meded Landbouwhoges Wagening 67:1-119.

$\rightarrow-1993$ Evolutionary trends in secondary phloem anatomy of trees, shrubs and climbers from Africa (mainly Ivory Coast). Acta Bot Neerl 42:269-287.

$\rightarrow$ Dunn MT 2006 A review of permineralized seed fern stems of the Upper Paleozoic. J Torrey Bot Soc 133:20-32.

$\rightarrow$ Dunn MT, M Krings, G Mapes, GW Rothwell, RH Mapes, K Sun 2003a Medullosa steinii sp. nov., a seed fern vine from the Upper Mississippian. Rev Palaeobot Palynol 124:307-324.

$\rightarrow$ Dunn MT, GW Rothwell 2012 Phenotypic plasticity of the hydrasperman seed fern Tetrastichia bupatides Gordon (Lyginopteridaceae). Int J Plant Sci 173:823-834.

$\rightarrow$ Dunn MT, GW Rothwell, G Mapes $2003 b$ On Paleozoic plants from marine strata: Trivena arkansana (Lyginopteridaceae) gen. et sp. nov., a lyginopterid from the Fayetteville Formation (Middle Chesterian/Upper Mississippian) of Arkansas, USA. Am J Bot 90:12391252.

$\rightarrow$ Esau K 1948 Phloem structure in the grapevine, and its seasonal changes. Hilgardia 18:217-296.

1969 Handbuch der Pflanzenanatomie: the phloem. Borntraeger, Berlin.

$\rightarrow$ Ewers FW 1985 Xylem structure and water conduction in conifer trees, dicot trees, and lianas. IAWA Bull 6:309-317.

$\rightarrow$ Falcon-Lang HJ 1999 The Early Carboniferous (Courceyan-Arundian) monsoonal climate of the British Isles: evidence from growth rings in fossil woods. Geol Mag 136:177-187.

$\rightarrow$ Falcon-Lang HJ, AR Bashforth 2004 Pennsylvanian uplands were forested by giant cordaitalean trees. Geology 32:417-420.

$\rightarrow$ Franceschi VR, T Krekling, AA Berryman, E Christiansen 1998 Specialized phloem parenchyma cells in Norway spruce (Pinaceae) bark are an important site of defense reactions. Am J Bot 85:601615.

$\rightarrow$ Furuno T 1990 Bark structure of deciduous broad-leaved trees grown in the San'in Region, Japan. IAWA Bull 11:239-254.

Galtier J 1970 Recherches sur les végétaux à structure conservée du Carbonifère inférieur français. Paleobiol Cont 1:41-221.

1974 Organization of the frond of Calamopitys, probable pteridospermales from the Lower Carboniferous. C R Acad Sci 279: 975-978.

1988 Morphology and phylogenetic relationships of early pteridosperms. Pages 135-176 in CB Beck, ed. Origin and evolution of gymnosperms. Columbia University Press, New York.

2002 Pitus, a giant tree of the Early Carboniferous time. Pages 34-37 in U Dernbach, WD Tidwell, eds. Secrets of petrified plants: fascination from millions of years. D'oro, Heppenheim.

$\rightarrow-2010$ The origins and early evolution of the megaphyllous leaf. Int J Plant Sci 176:641-661.

Galtier J, CB Beck 1992 Triichnia, a new eustelic calamopityacean from the Lower Carboniferous of France. Palaeontographica 224B: $1-16$.

Galtier J, RE Brown, AC Scott, GM Rex, NP Rowe 1993a A Late Dinantian flora from Weaklaw, East Lothian, Scotland. Palaeontol Spec Pap 49:57-74.

Galtier J, C Hébant 1973 Sur le phloème et le cambium d'une Calamopityacée, ptéridospermale probable du Carbonifère inférieur français. C R Acad Sci 276D:2257-2259.

$\rightarrow$ Galtier J, B Meyer-Berthaud 1996 The early seed plant Tristichia tripos (Unger) comb. nov. from the Lower Carboniferous of Saalfeld, Thuringia. Rev Palaeobot Palynol 93:299-315.

$\rightarrow-2006$ The diversification of early arborescent seed ferns. J Torrey Bot Soc 133:7-19.

Galtier J, B Meyer-Berthaud, CB Beck 1993b Large Calamopitys stems from the Tournaisian of France. Palaeontogr Abt B Palaeophytol 230:59-79.

Galtier J, TL Phillips 1999 The acetate peel technique. Pages 67-70 in TP Jones, NP Rowe, eds. Fossil plants and spores: modern techniques. Geological Society, London.

$\rightarrow$ Galtier J, J-L Schneider, L Grauvogel-Stamm 1998 Arborescent gymnosperms and the occurrence of Protopitys from the Lower Carboniferous of the Vosges, France. Rev Palaeobot Palynol 99:203215.

$\rightarrow$ Galtier J, AC Scott 1991 Stanwoodia, a new genus of probable early gymnosperms from the Dinantian of East Kirkton, Scotland. Trans R Soc Edinb 82:113-123.

$\rightarrow-1994$ Arborescent gymnosperms from the Viséan of East Kirkton, West Lothian, Scotland. Trans R Soc Edinb 84:261-266.

Ghouse AKM, S Hashmi 1980 Periodicity of cambium and the formation of xylem and phloem in Mimusops elengi L., an evergreen member of tropical India. Flora 173:470-487.

$\rightarrow$ Gordon WT 1912 On Rhetinangium arberi, a new genus of Cycadofilices from the Calciferous Sandstone series. Trans R Soc Edinb $48: 813-825$

$\rightarrow \quad 1938$ On Tetrastichia bupatides, a Carboniferous pteridosperm from East Lothian. Trans R Soc Edinb 59:351-370.

Greguss P 1968 Xylotomy of the living Cycads, with a description of their leaves and epidermis. Akadémiai Kiadó, Budapest.

Grillos SJ, FH Smith 1959 The secondary phloem of Douglas-fir. For Sci 5:377-388.

$\rightarrow$ Hall JW 1952 The phloem of Heterangium americanum. Am Midl Nat 47:763-768.

Hass H, NP Rowe 1999 Thin sections and wafering. Pages 76-81 in TP Jones, NP Rowe, eds. Fossil plants and spores: modern techniques. Geological Society, London.

$\rightarrow$ Henderson E, HJ Falcon-Lang 2011 Diversity and ontogeny of Pitus tree-trunks in the early Mississippian rocks of the Isle of Bute, Scotland: the importance of sample size and quantitative analysis for fossil wood systematics. Rev Palaeobot Palynol 166:202-212.

$\rightarrow$ Hilton J, RM Bateman 2006 Pteridosperms are the backbone of seed plant phylogeny. J Torrey Bot Soc 133:119-168.

Holdheide W 1951 Anatomie mitteleuropäischer Gehölzrinden (mit mikrophotographischem Atlas). Handb Mikrosk Tech 5:195-367.

Kenrick PR, PR Crane 1997 The origin and early diversification of land plants: a cladistic study. Smithsonian Institution, Washington, DC.

Kotina EL, B-E Van Wyk, PM Tilney, AA Oskolski 2012 The system- 
atic significance of bark structure in southern African genera of tribe Heteromorpheae (Apiaceae). Bot J Linn Soc 169:677-691.

Lemoigne Y, A Iurina, N Snigirevskaya 1983 Revision du genre Callixylon Zalessky 1911 (Archaeopteris) du Devonien. Palaeontographica 186B:81-120.

$\rightarrow$ Liu D, X Gao 1993 Comparative anatomy of the secondary phloem of ten species of Rosaceae. IAWA J 14:289-298.

Long AG 1961 Tristichia ovensi gen. et sp. nov., a protostelic Lower Carboniferous pteridosperm from Berwickshire and East Lothian, with an account of some associated seeds and cupules. Trans $\mathrm{R}$ Soc Edinb 64:477-492.

$\rightarrow-1979$ Observations on the Lower Carboniferous genus Pitus Witham. Trans R Soc Edinb 70:111-127.

$\rightarrow$ Masselter T, NP Rowe, J Galtier, T Speck 2009 Secondary growth and deformation of stem tissues in the Lower Carboniferous seed fern Calamopitys. Int J Plant Sci 170:1228-1239.

$\rightarrow$ Meyer-Berthaud B, A-L Decombeix, X Ermacora 2013 Archaeopterid root anatomy and architecture: new information from permineralized specimens of Famennian age. Int J Plant Sci 174:364-381.

$\rightarrow$ Meyer-Berthaud B, SE Scheckler, J Wendt 1999 Archaeopteris is the earliest known modern tree. Nature 398:700-704.

$\rightarrow$ Oskolski AA, EL Kotina, IV Fomichev, F Tronchet, PP Lowry II 2007 Systematic implications of wood and bark anatomy in the Pacific Island genus Meryta (Araliaceae). Bot J Linn Soc 153:363-379.

$\rightarrow$ Pace MR, V Angyalossy 2013 Wood anatomy and evolution: a case study in the Bignoniaceae. Int J Plant Sci 174:1014-1048.

$\rightarrow$ Petit RJ, A Hampe 2006 Some evolutionary consequences of being a tree. Annu Rev Ecol Evol Syst 37:187-214.

Prestianni C, A-L Decombeix 2013 Seed plant evolution around the Devonian/Carboniferous boundary: reproductive vs. vegetative disparity. Abstract 360 presented at the Annual Meeting of the Botanical Society of America, New Orleans, July 27-31.

$\rightarrow$ Prestianni C, J Hilton, W Cressler 2013 Were all Devonian seeds cupulate? a reinvestigation of Pseudosporogonites hallei, Xenotheca bertrandii, and Aglosperma spp. Int J Plant Sci 174:832-851.

Rothwell GW 1988 Cordaitales. Pages 273-297 in CB Beck, ed. Origin and evolution of gymnosperms. Columbia University Press, New York.

$\rightarrow$ Rothwell GW, R Serbet 1994 Lygnophyte phylogeny and the evolution of spermatophytes: a numerical cladistic analysis. Syst Bot 19: $443-482$.

$\rightarrow$ Rothwell GW, TN Taylor 1972 Carboniferous pteridosperm studies: morphology and anatomy of Schopfiastrum decussatum. Can J Bot 50:2649-2658.

$\rightarrow$ Rowe NP, T Speck, J Galtier 1993 Biomechanical analysis of a Palaeozoic gymnosperm stem. Proc R Soc B 252:19-28.

$\rightarrow$ Russin WA 1981 Secondary phloem of the Paleozoic pteridosperm Callistophyton boyssetii (Renault) Rothwell. Bot Gaz 142:165-175.

$\rightarrow$ Ryberg PE, EL Taylor, TN Taylor 2007 Secondary phloem anatomy of Cycadeoidea (Bennettitales). Am J Bot 94:791-798.

$\rightarrow$ Salleo S, M Logullo, D Depaoli, M Zippo 1996 Xylem recovery from cavitation-induced embolism in young plants of Laurus nobilis: a possible mechanism. New Phytol 132:47-56.

$\rightarrow$ Scheckler SE, HP Banks 1971a Anatomy and relationships of some Devonian progymnosperms from New York. Am J Bot 58:737-751.

$\rightarrow-1971 b$ Proteokalon, a new genus of progymnosperm from the Devonian of New York State and its bearing on phylogenetic trends in the group. Am J Bot 58:874-884.

$\rightarrow$ Scott AC, J Galtier 1996 A review of the problems in the stratigraphical palaeoecological and palaeobiogeographical interpretation of
Lower Carboniferous (Dinantian) floras from western Europe. Rev Palaeobot Palynol 90:141-153.

Scott DH 1912 The structure of Mesoxylon lomaxii and M. poroxyloides. Ann Bot 26:1011-1030.

1918 The structure of Mesoxylon multirame. Ann Bot 32: 437-457.

$\rightarrow$ Serbet R, GW Rothwell 1992 Characterizing the most primitive seed ferns. I. A reconstruction of Elkinsia polymorpha. Int J Plant Sci 153:602-621.

$\rightarrow$ Smoot EL 1984a Phloem anatomy of the Carboniferous pteridosperm Medullosa and evolutionary trends in gymnosperm phloem. Bot Gaz 145:550-564.

$\rightarrow \longrightarrow 1984 b$ Secondary phloem anatomy in Callistophyton boyssetii (Renault) Rothwell and histological changes in the outer phloem. Bot Gaz 145:395-406.

Solms-Laubach H Graf zu 1893 Ueber die in den Kalksteinen des Culm von Glätzisch Falkenberg in Schlesien enthaltenen Structur bietenden Pflanzenreste. III. Abhandlung. Bot Zeitung 51:197-209.

$\rightarrow$ Speck T, NP Rowe 2003 Modelling primary and secondary growth processes in plants: a summary of the methodology and new data from an early lignophyte. Philos Trans R Soc B 358:1473-1485.

$\rightarrow$ Stein WE, CB Beck 1978 Bostonia perplexa gen. et. sp. nov., a calamopityan axis from the New Albany Shale of Kentucky. Am J Bot 65:459-465.

1983 Triloboxylon arnoldii from the Middle Devonian of western New York. Contrib Mus Paleontol Univ Mich 26:257-288.

Stein WE, CM Berry, LVA Hernick, F Mannolini 2012 Surprisingly complex community discovered in the mid-Devonian fossil forest at Gilboa. Nature 483:78-81.

$\rightarrow$ Stewart WN 1951 Medullosa pandurata sp. nov. from the McLeansboro group of Illinois. Am J Bot 38:709-717.

$\rightarrow$ Stubblefield SP, GW Rothwell 1989 Cecropsis luculentum gen. et sp. nov.: evidence for heterosporous progymnosperms in the Upper Pennsylvanian of North America. Am J Bot 76:1415-1428.

$\rightarrow$ Taylor EL 1988 Secondary phloem anatomy in cordaitean axes. Am J Bot 75:1655-1666.

1990 Phloem evolution: an appraisal based on the fossil record. Pages 285-298 in HD Behnke, RD Sjolund, eds. Sieve elements: comparative structure, induction and development. Springer, Berlin.

$\rightarrow$ Walton J 1969 On the structure of a silicified stem of Protopitys and roots associated with it from the Carboniferous Limestone, Lower Carboniferous (Mississippian) of Yorkshire, England. Am J Bot 56: 808-813.

$\rightarrow$ Wang S-J, J Hilton, B Tian, J Galtier 2003 Cordaitalean seed plants from the Early Permian Taiyuan Formation of North China. I. Delimitation and reconstruction of the whole-plant Shanxioxylon sinense. Int J Plant Sci 164:89-112.

$\rightarrow$ Whitmore TC $1962 a$ Studies in systematic bark morphology. I. Bark morphology in Dipterocarpaceae. New Phytol 61:191-207.

$\rightarrow \quad 1962 b$ Studies in systematic bark morphology. II. General features of bark construction in Dipterocarpaceae. New Phytol 61:208220.

$\rightarrow$ Williamson WC, DH Scott 1895 Further observations on the organization of the fossil plants of the Coal-Measures. III. Lyginodendron and Heterangium. Philos Trans R Soc B 186:703-779.

$\rightarrow$ Zwieniecky MA, PJ Melcher, TS Field, NM Holbrook 2004 A potential role for xylem-phloem interactions in the hydraulic architecture of trees: effects of phloem girdling on xylem hydraulic conductance. Tree Physiol 24:911-917. 